\title{
Utility of cyanoacetic acid hydrazide in heterocyclic synthesis
}

\author{
Samir Bondock,*Abd El-Gaber Tarhoni, and Ahmed A. Fadda \\ Department of Chemistry, Faculty of Science, Mansoura University, ET-35516 Mansoura, Egypt \\ E-mail: Bondock@mans.edu.eg
}

\begin{abstract}
This review describes the synthesis and reactions of cyanoacetic acid hydrazide as building block for the synthesis of polyfunctionalized heterocyclic compounds with pharmacological interest.
\end{abstract}

Keywords: Cyanoacetic acid hydrazide, pyrazoles, thiadiazoles, pyridines, pyrans, pyridazines, pyrimidines, annelated heterocycles

\section{Contents}

1. Introduction

2. Synthesis of Cyanoacetic Acid Hydrazide

3. Chemical Reactivity

4. Reactions of Cyanoacetic Acid Hydrazide

4.1. Synthesis of five-membered rings with one heteroatom

4.1.1. Thiophenes and their fused derivatives

4.2. Synthesis of five-membered rings with two heteroatoms

4.2.1. Pyrazoles and their fused derivatives

4.2.2. Thiazoles and their fused derivatives

4.3. Synthesis of five-membered rings with three heteroatoms

4.3.1. Triazoles and their fused derivatives

4.3.2. Thiadiazoles

4.4. Synthesis of six-membered rings with one heteroatom

4.4.1 Pyridines and their fused derivatives

4.4.2. Pyrans and their fused derivatives

4.4.3. Thiopyrans

4.5. Synthesis of six-membered rings with two heteroatoms

4.5.1 Pyridazines and their fused derivatives

4.5.2 Pyrimidines and their fused derivatives

4.6. Synthesis of six-membered rings with three heteroatoms 
4.6.1. Thiadiazines

4.6.2. Triazine

5. Conclusions

6. References

\section{Introduction}

Cyanoacetic acid hydrazide is a versatile and convenient intermediate for the synthesis of wide variety of heterocyclic compounds. The $\beta$-functional nitrile $\mathrm{e}^{1-4}$ moiety of the molecule is a favorable unit for addition followed by cyclization or via cycloaddition with numerous reagents providing heterocyclic compounds of different ring sizes with one or several heteroatoms that are interesting as pharmaceuticals, ${ }^{5,6}$ as herbicides, ${ }^{7}$ as antibacterial agents, ${ }^{8}$ and as dyes. ${ }^{9,10}$ Their reactions with dinucleophiles usually result in the formation of polycyclic ring systems which may be the skeleton of important heterocylic compounds. In previous publications, novel synthesis of azoles, ${ }^{11,12}$ azines, ${ }^{13}$ and azoloazines, ${ }^{14}$ had been reported utilizing $\beta$-functional nitriles as starting components. Among the $\beta$-functional nitriles, cyanoacetic acid hydrazide and their analogues are especially important starting materials or intermediates for the synthesis of various nitrogen-containing heterocyclic compounds. Our research deals with the effective use of cyanoacetic acid hydrazide in the synthesis of a variety of polyfunctional heterocyclic compounds with biological interest.

\section{Synthesis of Cyanoacetic Acid Hydrazide}

Cyanoacetic acid hydrazide was obtained by careful addition of hydrazine hydrate to ethyl cyanoacetate in ethanol with stirring at $0{ }^{\circ} \mathrm{C} .^{15}$<smiles>CCOC(=O)CC#N</smiles>

1
$\mathrm{NH}_{2} \mathrm{NH}_{2}$
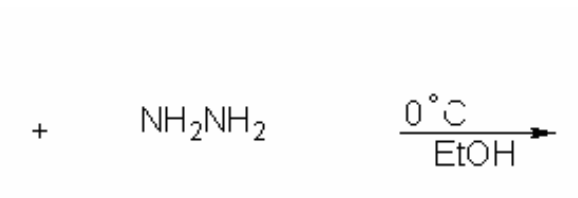

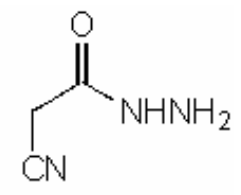

2

\section{Scheme 1}




\section{Chemical Reactivity}

Cyanoacetic acid hydrazide can act as an ambident nucleophile, that is, as both an $N$ - and a $C$ nucleophile. On treatment of cyanoacetic acid hydrazide with various reagents, the attack can take place at five possible sites: the nucleophile is able to attack the carbon of the carbonyl function (position 3) and the carbon atom of the nitrile function (position 5). While the active methylene group (position 4) and amino groups (positions 1 and 2) are able to attack electrophiles.

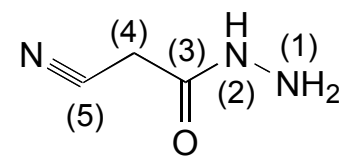

\section{Reactions of Cyanoacetic Acid Hydrazide}

The reactions of cyanoacetic acid hydrazide with numerous reagents are classified separately in one category due to the huge number of references. We have arranged this huge volume of data in terms of the type of the heterocycles formed, starting with five and six membered rings in order of increasing number of heteroatoms. Such systematic treatment provides a clear idea about the synthetic possibilities of the method and may be useful in selecting the direction of further research.

\subsection{Synthesis of five-membered rings with one heteroatom}

\subsubsection{Thiophenes and their fused derivatives}

Reaction of compound $\mathbf{2}$ with cyclic ketones and sulfur in the presence of morpholine under Gewald reaction conditions afforded thiophene derivatives $\mathbf{3}$ and $\mathbf{4} .^{16}$ 


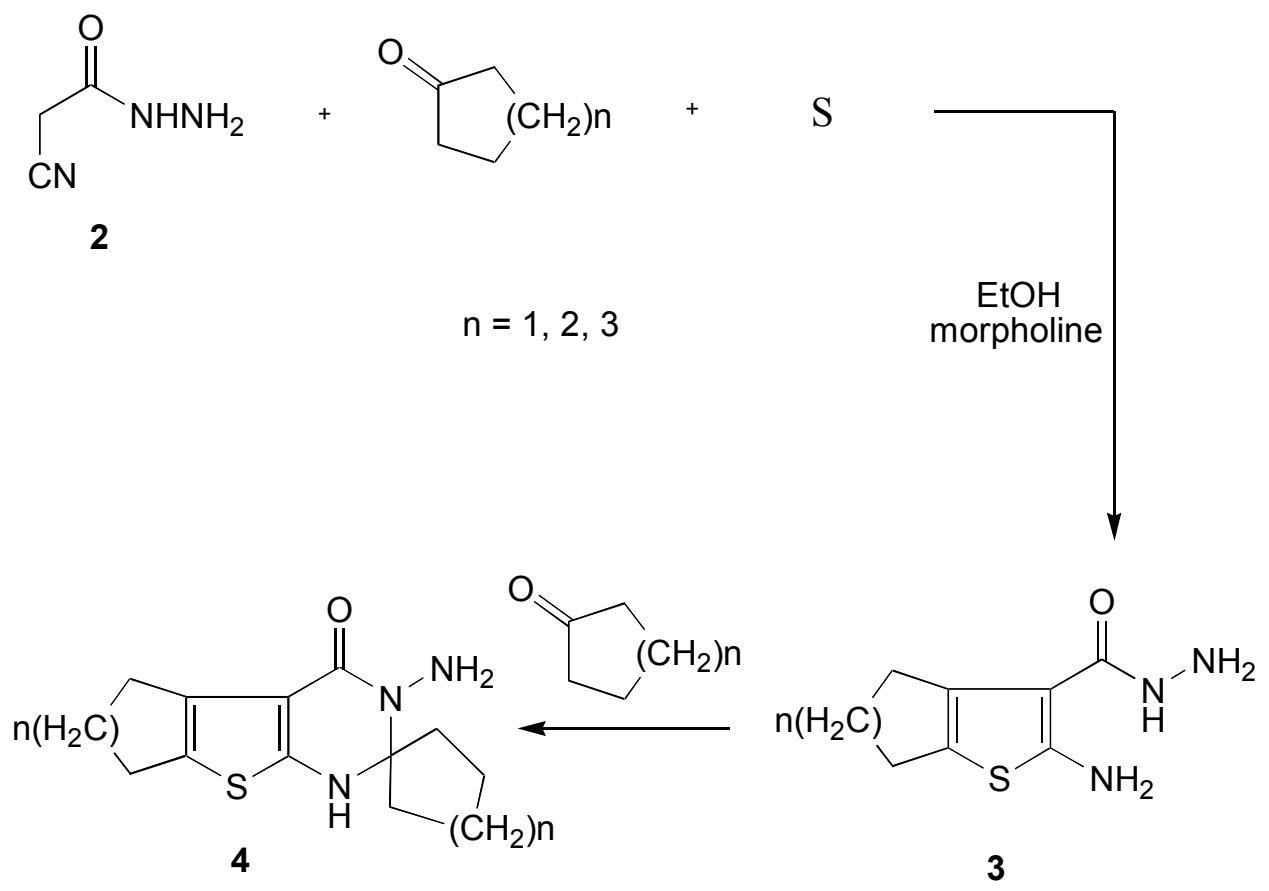

\section{Scheme 2}

\subsection{Synthesis of five-membered rings with two heteroatoms}

\subsubsection{Pyrazoles and their fused derivatives}

Treatment of 2 in water containing a catalytic amount of conc. $\mathrm{HCl}$ with acetyl acetone at room temperature afforded 1-cyanoacetyl-3, 5-dimethyl pyrazole $\mathbf{5}^{15}$<smiles>CC(=O)CC(C)=O</smiles>

2

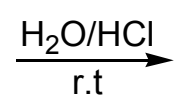<smiles>CCC(=O)n1nc(C)cc1C</smiles>

\section{Scheme 3}

The reaction of $\mathbf{2}$ with alkylisocyanate yields alkylcarbamoyl derivative $\mathbf{6}$ that cyclized into pyrazole derivative 7 up on treatment with $2 \mathrm{~N}$ sodium hydroxide. ${ }^{17}$ 
<smiles>N#CCC(=O)NN</smiles>

2

\begin{tabular}{l|l}
$\mathbf{6 , 7}$ & $\mathrm{R}$ \\
\hline $\mathrm{a}$ & $\mathrm{H}$ \\
$\mathrm{b}$ & $\mathrm{Me}$ \\
$\mathrm{c}$ & $\mathrm{Ph}$
\end{tabular}

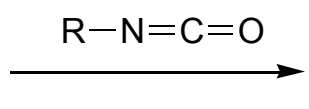<smiles>[R]NC(=O)n1nc(O)cc1N</smiles>

7<smiles>[R]NC(=O)NNC(=O)CC#N</smiles>

6<smiles>CC(C)O[N+](=O)[O-]</smiles>

\section{Scheme 4}

Refluxing of 2 with phenyl isothiocyanate in basic dioxane solution afforded pyrazolinone derivative 8. Treatment of $\mathbf{8}$ with malononitrile in DMF in the presence of piperidine gave [(3amino-5-imino-4,5-dihydro-1H-pyrazol-1-yl)(anilino)methylene]malononitrile 9, which underwent cyclocondensation with hydrazine hydrate to give pyrazolo[1,5-a]pyrimidine derivative 10. ${ }^{18}$

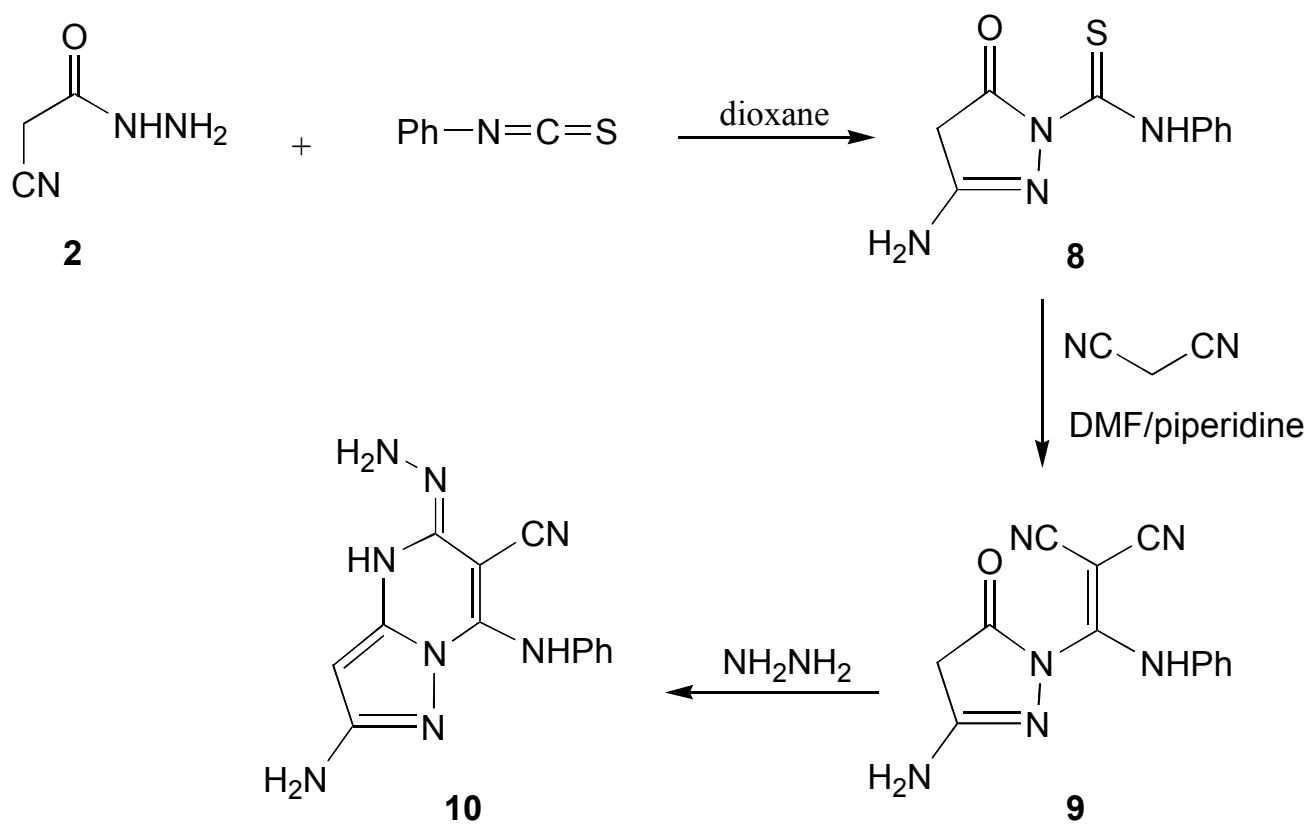

\section{Scheme 5}

5-Amino-3-hydroxypyrazole derivatives 12 were prepared from the reaction of 2 with ketones in the presence of a basic catalyst via the cyclization of hydrazone derivatives $\mathbf{1 1}{ }^{19}$ 
<smiles>[R]C([R])=NNC(=O)CC#N</smiles>

\begin{tabular}{c|l}
$\mathbf{1 1 , 1 2}$ & $\mathrm{CHR}_{1} \mathrm{R}_{2}$ \\
\hline $\mathrm{a}$ & $\mathrm{CHMe}_{2}$ \\
$\mathrm{~b}$ & $\mathrm{CHMeEt}$ \\
$\mathrm{c}$ & cyclopentyl \\
d & cyclohexyl \\
e & heterocycl
\end{tabular}<smiles>[R2][R]n1nc(O)cc1N</smiles>

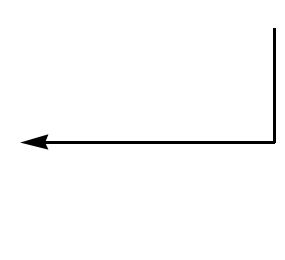

12

\section{Scheme 6}

Elnagdi and coworkers have reported the reaction of 2-(1-phenylethylidene)malononitrile with 2 furnished pyrazoline derivative $13{ }^{20}$

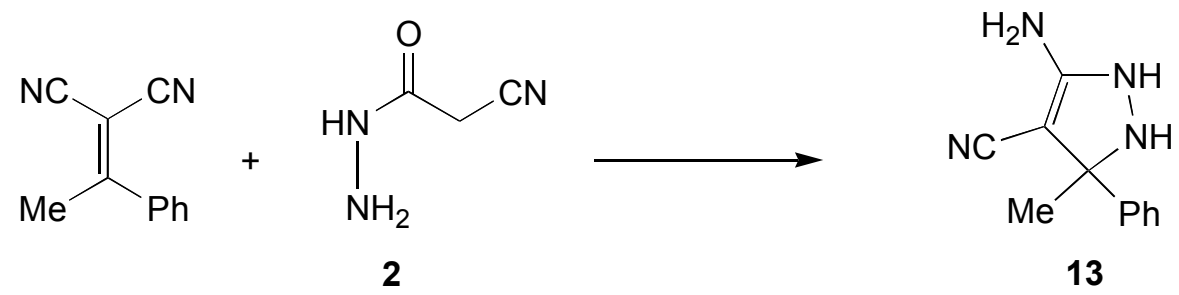

\section{Scheme 7}

Pyrazolidinone derivative 14 was obtained by treatment of 2 with ethyl 2-cyano-3phenylbut-2-enoate. ${ }^{20}$<smiles>CCOC(=O)/C(C#N)=C(/C)c1ccccc1</smiles>

$$
\mathrm{Me} \mathrm{Ph}
$$<smiles>N#CCC(=O)NN</smiles>

2<smiles>CC1(c2ccccc2)NNC(=O)C1C#N</smiles>

14

\section{Scheme 8}

Cyanoaceto- $N$-arylsulfonylhydrazide $\mathbf{1 5}$ on refluxing in ethanol containing a catalytic amount of piperidine, ${ }^{21}$ or in presence of potassium hydroxide, ${ }^{22}$ undergo intramolecular 
cyclization to give the 5-amino-1-arylsulfonyl-4-pyrazolin-3-one or the tautomeric 5-amino-1arylsulfonyl-3-hydroxypyrazole structure 17.

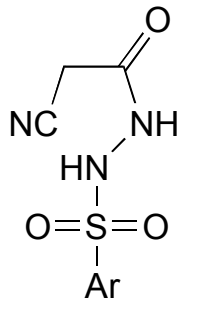

15
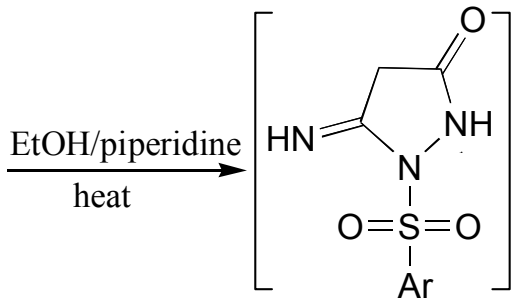

16

\section{Scheme 9}

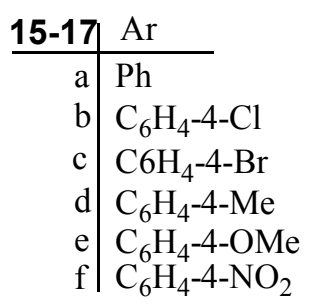

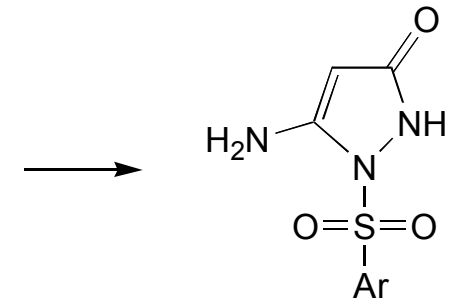

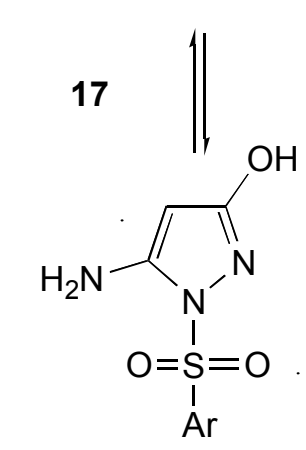

The reaction of $\mathbf{2}$ with isatin in ethanol containing a catalytic amount of triethylamine at room temperature furnished the isolated intermediate (2E)-2-cyano-2-(2-oxo-1,2-dihydro-3Hindol-3-ylidene)acetohydrazide 18 which cyclized under heating to give (2E)-3-(3-amino-5-oxo1,5-dihydro-4H-pyrazol-4-ylidene)-1,3-dihydro-2 $H$-indol-2-one $19 .{ }^{23}$ 


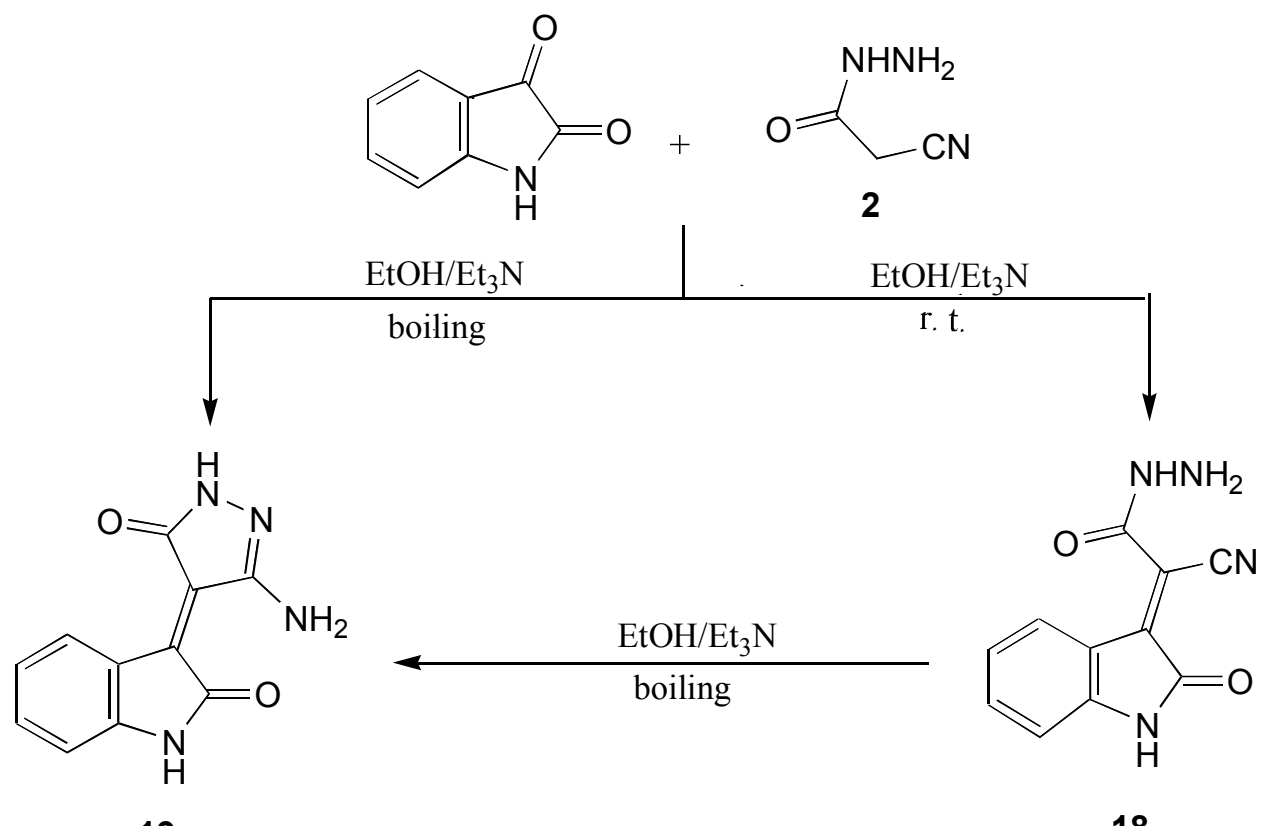

19

18

\section{Scheme 10}

Condensation of hydrazone derivative 11d with aromatic aldehyde in ethanolic triethyl amine gave the unexpected 3-aryl-4,5,6,7-tetrahydro- $1 H$-indazole $21 .^{24}$

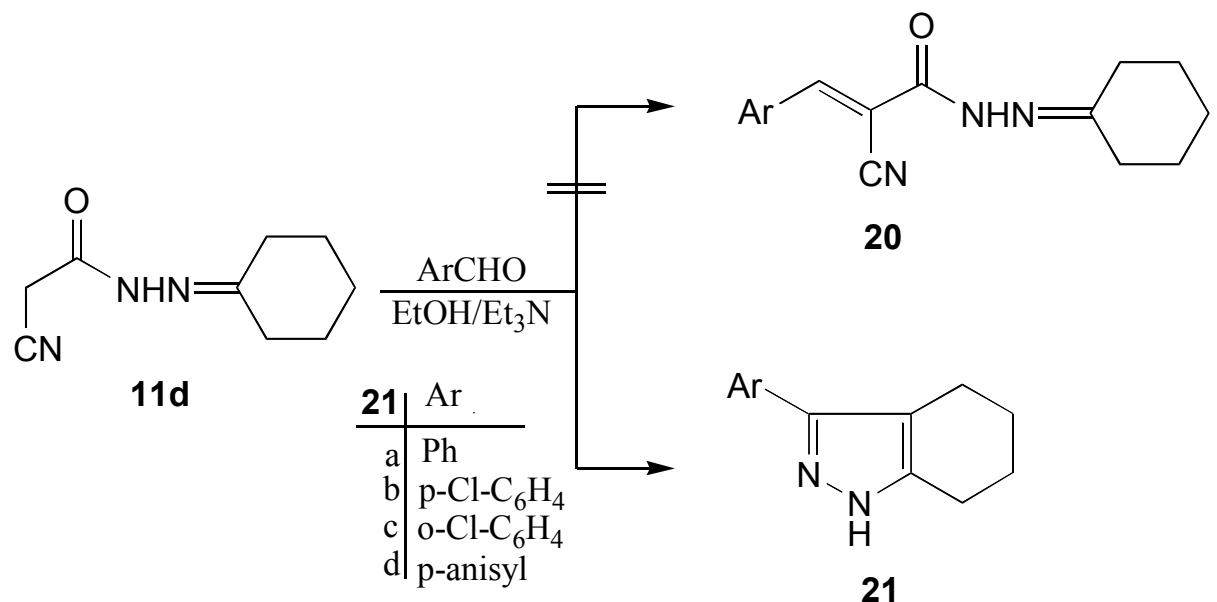

\section{Scheme 11}

Treatment of 2 with phenyl 7-fluoro-4-chromone-3-sulfonate in presence of sodium acetate and glacial acetic acid at $100^{\circ} \mathrm{C}$ afforded a mixture of 7-fluoro-2 $\mathrm{H}-[1,2]$ benzoxathiino[4,3c]pyrazole 4,4-dioxide $\mathbf{2 2}$ and 1-amino-8-fluoro-2-oxo-1,2,3,10b-tetrahydro[1,2] benzoxathiino[4,3-b]pyridine-3-carbonitrile 5,5-dioxide $23 .{ }^{25}$ 


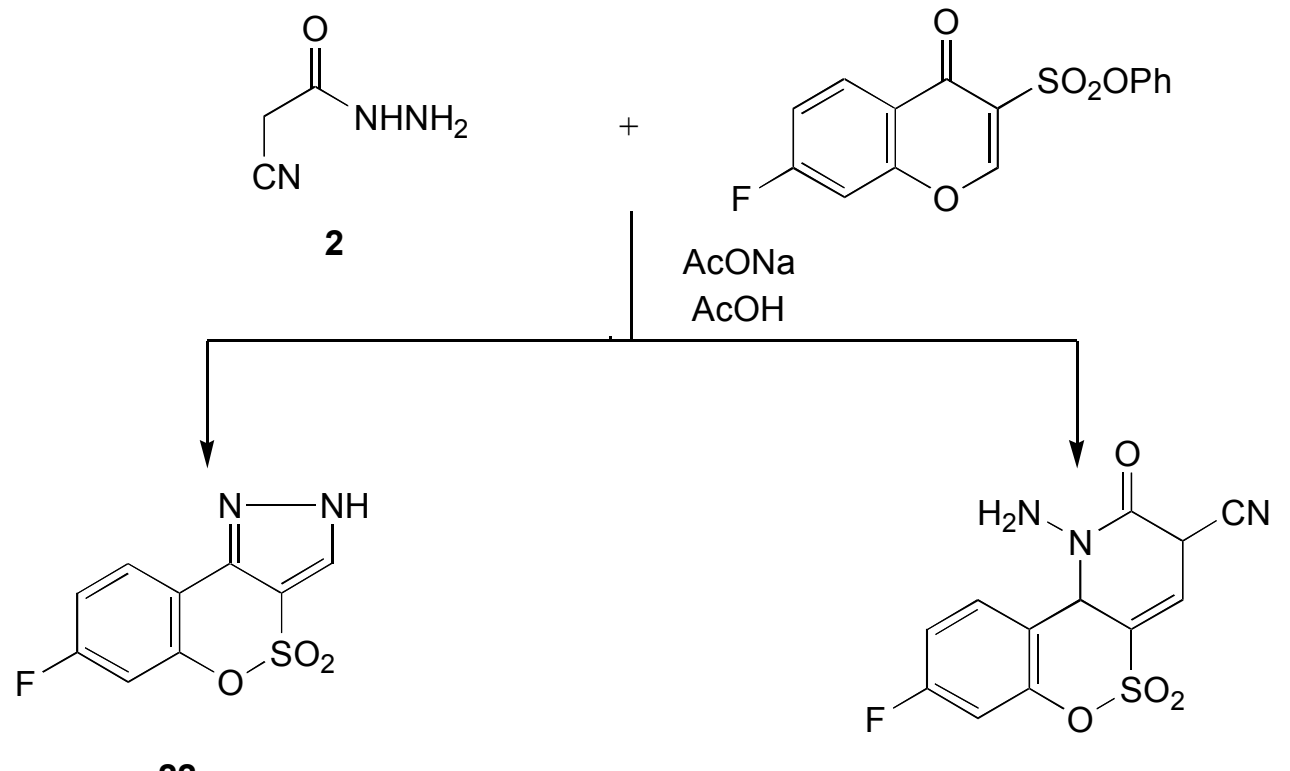

22

23

\section{Scheme 12}

Reaction of 2 with ethyl benzoylacetate at $140-150^{\circ} \mathrm{C}$ yield $1 N$-cyanoacetyl- $2 N$ benzoylacetylhydrazine $\mathbf{2 4}$ which underwent cyclocondensation with 3-hydrazino-5,6-diphenyl1,2,4-triazine in absolute ethanol to yield compound 25 that when treated with dil. hydrochloric acid gives 1-[1-(5,6-diphenyl-1,2,4-triazin-3-yl)-4-phenyl-1H-pyrazol-3-yl]pyrazolidine-3,5dione 26. ${ }^{26}$<smiles>N#CCC(=O)NN</smiles>

2<smiles>N#CCC(=O)NNc1cc(-c2ccccc2)n(-c2nnc(-c3ccccc3)c(-c3ccccc3)n2)n1</smiles>

\section{Scheme 13}


Cycloaddition of 2 with arylidene of 2-cyanomethyl-1,3-benzothiazole yielded 3-aryl-2(1,3-benzothiazol-2-yl)-3-(5-imino-3-oxopyrazolidin-1-yl)propanenitrile $27 .^{27}$<smiles>N#C/C(=C/[Ga])c1nc2ccccc2s1</smiles><smiles>N#CC(=O)NN</smiles>

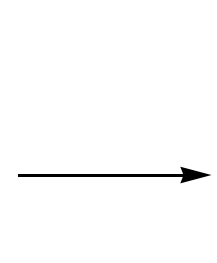

2

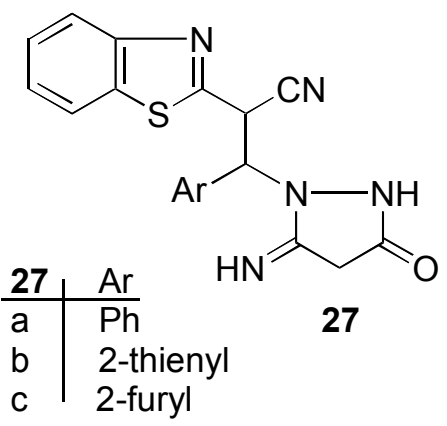

\section{Scheme 14}

Compound 2 reacts with hydrazone derivatives in refluxing dioxane containing a catalytic amount of triethylamine to yield pyrazoloazine derivatives $\mathbf{3 0}{ }^{28}$<smiles>[R]NN=C([X])C(=O)OCC</smiles>

2<smiles>[R]NN=C([X])C(=O)NNC(=O)CCCC</smiles>

28

a, $\mathrm{X}=\mathrm{CN}$

b, $X=\mathrm{COCH}_{3}$<smiles>[R]C1CCc2sc(C)c(C(N)=O)c2C1</smiles><smiles>[R]N=Nc1[X]2cc(N)cc(O)n2nc1O</smiles>

30 a, $X=N$

b, $X=C H$<smiles>[R]N=Nc1c(O)nn(C(=O)CC)c1[X]</smiles>

29

a, $\mathrm{X}=\mathrm{NH}_{2}$

b, $\mathrm{X}=\mathrm{CH}_{3}$

\section{Scheme 15}




\subsubsection{Thiazoles and their fused derivatives}

Reaction of 2 with carbon disulfide in DMF and potassium hydroxide had been reported to afford nonisolable intermediate $\mathbf{3 1}$ that transformed into thiazole derivative $\mathbf{3 2}$ by the action of phenacyl bromide. On the other hand treatment of compound 32 with salicylaldehyde gave the $2 \mathrm{H}$-chromen-2-one derivative $\mathbf{3 4}$ via the nonisolable arylidene $\mathbf{3 3}$ followed by intramolecular addition of hydroxy group to the nitrile function. ${ }^{29}$<smiles>Cc1csc(=S)n1NC(=O)c1cc2ccccc2oc1=O</smiles>

33

\section{Scheme 16}

Condensation of 2 with 3,5-dimethyl-1-phenyl- $1 H$-pyrazole-4-carbaldehyde in ethanol under reflux afforded $N$-(3,5-dimethyl-1-phenyl-1H-pyrazole-4-methylidene) cyanoacetic acid hydrazide 35. The conversion of $\mathbf{3 5}$ into thiazole derivatives $\mathbf{3 6}$ was achieved by Gewald reaction, by reacting 35 with sulfur and appropriate aryl isothiocyanate in the presence of mixture of dimethylformamide and ethanol containing triethylamine as a basic catalyst. ${ }^{30}$ 


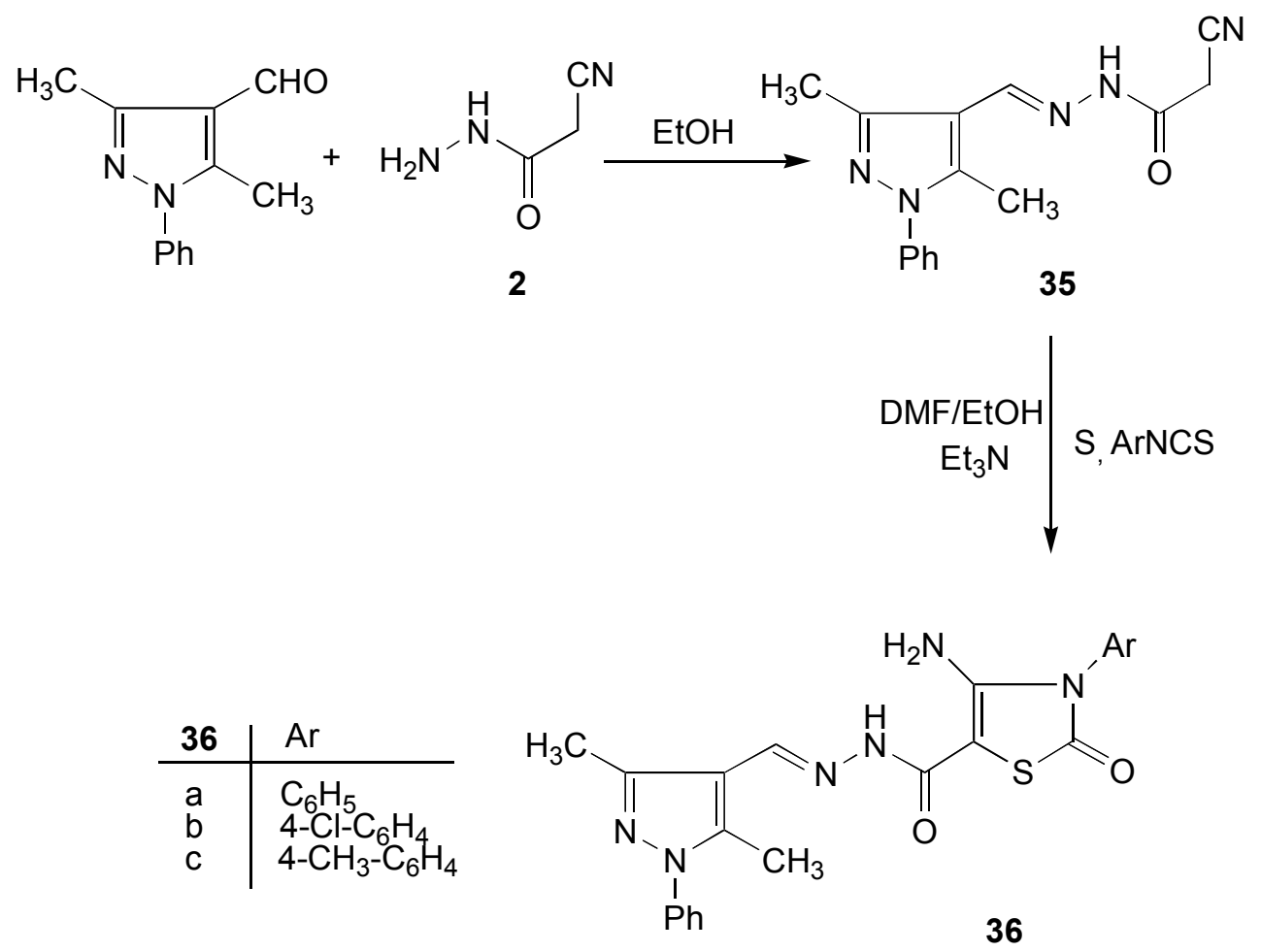

Scheme 17

\subsection{Synthesis of five-membered rings with three heteroatoms}

\subsubsection{Triazoles and their fused derivatives}

Cyclocondensation of 1-cyanoacetyl-4-phenylthiosemicarbazide 37 under basic conditions afforded 1, 2, 4-triazole derivative $38 .^{31}$<smiles>N#CCC(=O)NNC(=S)Nc1ccccc1</smiles>

37<smiles>N#CCc1n[nH]c(=S)n1-c1ccccc1</smiles>

38

\section{Scheme 18}

\section{Scheme 18}

By treating compound 2 with tert-butoxycarbonylhydrazone esters in an oil bath at $115^{\circ} \mathrm{C}$, 1,2,4-triazole derivative $\mathbf{4 2}$ was obtained. ${ }^{32}$ 


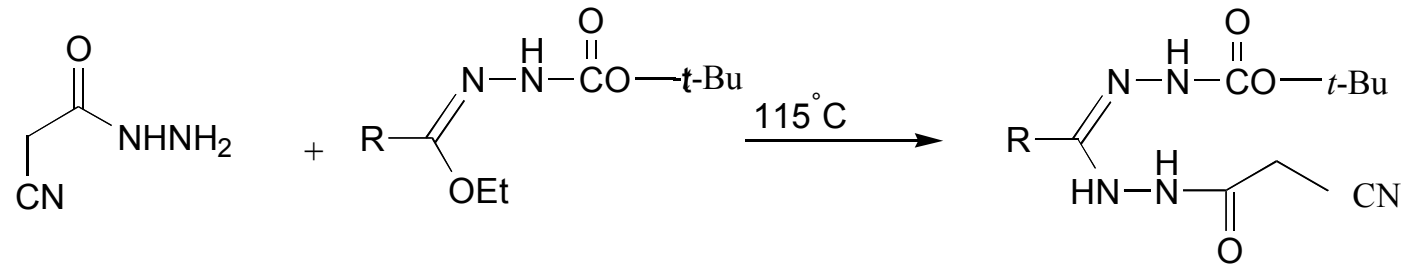<smiles>[R]c1nnc(CC#N)n1N</smiles>

42<smiles>[R]c1nnc(CC#N)n1NC(=O)OC(C)C</smiles>

41<smiles>[R]C(C)=NNC(=O)CC</smiles>

40

\section{Scheme 19}

The reaction of 1-cyanoacetyl-4-phenylthiosemicarbazide 37 with ethyl iodide in DMF and in the presence of anhydrous potassium carbonate at room temperature gave 3-ethylsulfanyl-5cyanomethyl-4-phenyl-1,2,4-triazole 43 . $^{33}$

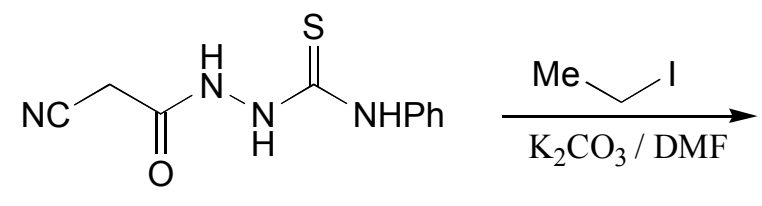

37<smiles>CCSc1nnc(CC#N)n1-c1ccccc1</smiles>

43

\section{Scheme 20}

The reaction of $\mathbf{2}$ with different hydrazones delivered 1,2,4-triazole derivatives $44 .^{34}$<smiles>N#CCC(=O)NN</smiles>

2<smiles>[R]/C(=N/NC(=O)OCC)OCC</smiles>

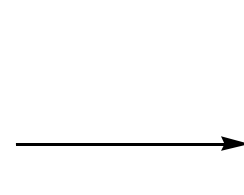

\section{Scheme 21}


Golovko and coworkers published the reaction of 2 with lactim ether furnished the 5,6dihydro-4H-[1,2,4]triazolo[4,3-a][1]benzazepin-1-ylacetonitrile $45^{35}$<smiles>N#CCC(=O)NN</smiles>

2<smiles>CCOC1=Nc2ccccc2CCC1</smiles>

45

Scheme 22

Treatment of 2 with 7-chloro-5-phenyl-1,3-dihydro- $2 H$-1,4 benzodiazepine-2-thione in the presence of a basic catalyst afforded 8-chloro-6-phenyl-4H-s- triazolo [4,3-a] [1,4] benzodiazepine-1-acetonitrile $\mathbf{4 6} .^{36}$<smiles>N#CCC(=O)NN</smiles>

2

46

\section{Scheme 23}

Refluxing of compound 25 in glacial acetic acid and anhydrous sodium acetate yielded [5(5,6-diphenyl-1,2,4-triazin-3-yl)-6-phenyl-5H-pyrazolo[5,1-c][1,2,4]triazol-3-yl]acetonitrile $47 .^{26}$<smiles>N#CCC(=O)NNc1cc(-c2ccccc2)n(-c2nnc(-c3ccccc3)c(-c3ccccc3)n2)n1</smiles>

Scheme 24 


\subsubsection{Thiadiazoles}

The reaction of 2 with phenylisothiocyanate in DMF in presence of sodium hydride gave nonisolable intermediate $\mathbf{4 8}$ that was converted into 1-cyanoacetyl-4-phenylthiosemicarbazide $\mathbf{3 7}$ by treatment with conc. hydrochloric acid. Heating of $\mathbf{3 7}$ with phosphorous oxychloride yielded (5anilino-1,3,4-thiadiazol-2-yl)acetonitrile 49. ${ }^{31,33}$

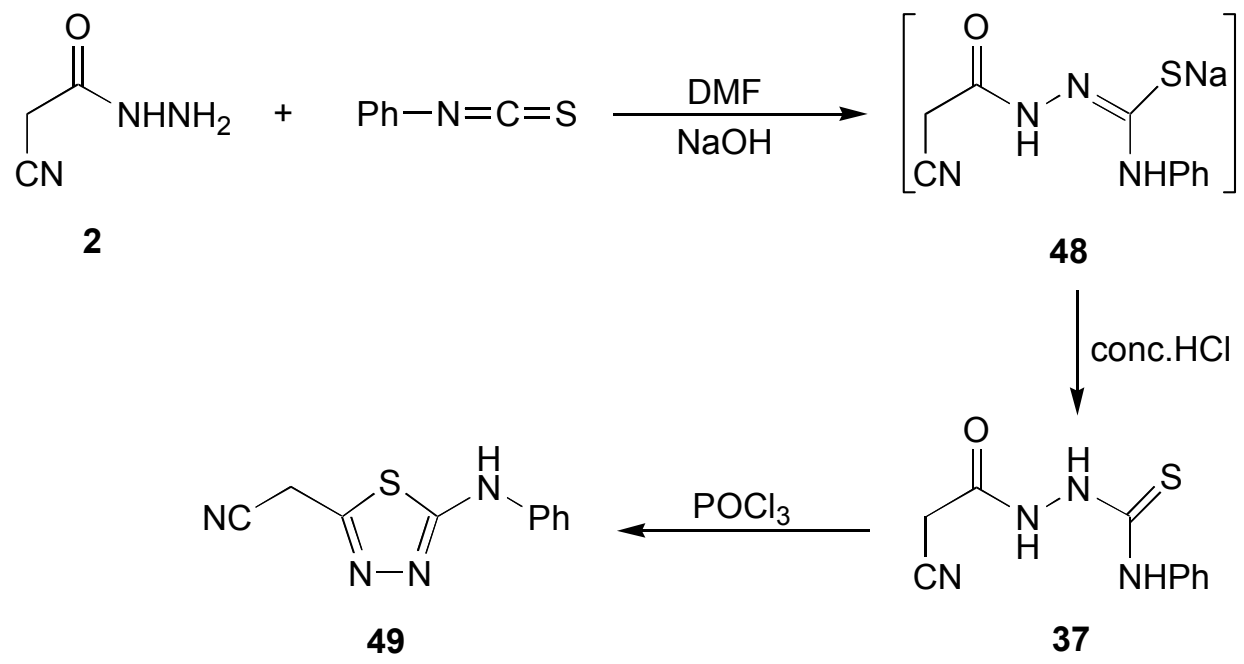

\section{Scheme 25}

Condensation of acylisothiocyanate with $\mathbf{2}$ in refluxing acetone gave $45 \%$ of thiocarbamoyl derivative $\mathbf{5 0}$ which underwent intramolecular cyclization in refluxing acetic acid to give $55 \% N$-[5-(cyanomethyl)-1,3,4-thiadiazol-2-yl]acetamide 51 . $^{37}$

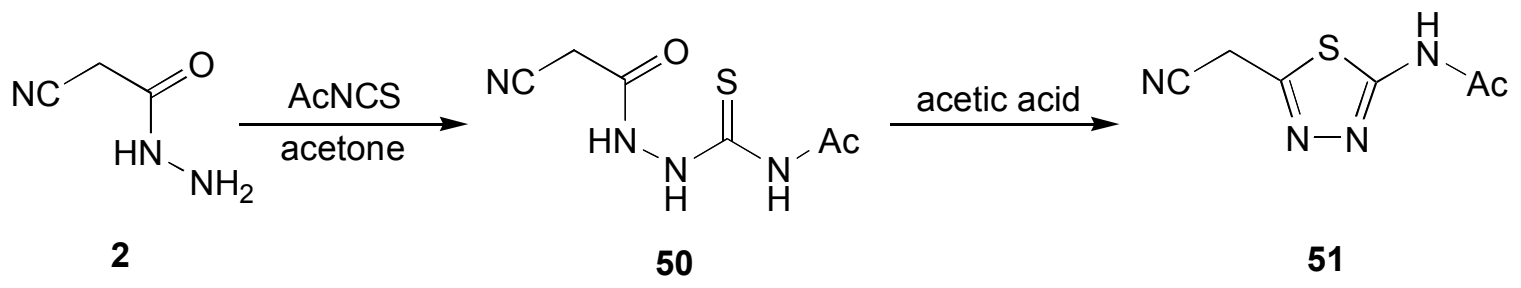

\section{Scheme 26}

\subsection{Synthesis of six-membered ring with one heteroatom}

\subsubsection{Pyridines and their fused derivatives}

Cyclocondensation of 2 with ethyl 3-aminocrotonate in methanol in the presence of potassium hydroxide under reflux afforded 1-amino-3-cyano-6-hydroxy-4-methyl-pyridine-2-one 52. ${ }^{38}$ 
<smiles>N#CCC(=O)NN</smiles>

2<smiles>CCOC(=O)/C=C(/C)N</smiles><smiles>CC(C)(O)O</smiles><smiles>Cc1cc(O)n(N)c(=O)c1C#N</smiles>

52

\section{Scheme 27}

Cyclocondensation of $\mathbf{2}$ with benzoylacetone and/or benzoyl trifluoroacetone in refluxing ethanol containing a catalytic amount of diethyl amine yielded regioselectively 1-amino-4-alkyl2-oxo-6-phenyl-1,2-dihydropyridine-3-carbonitrile 53. ${ }^{39-40}$<smiles>N#CCC(=O)NN</smiles>

2<smiles>[R]C(=O)CC(=O)c1ccccc1</smiles>

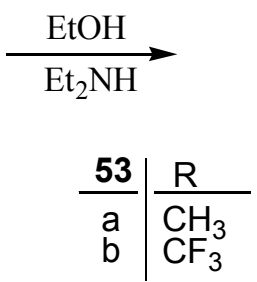<smiles>[R]c1cc(-c2ccccc2)n(N)c(=O)c1C#N</smiles>

53

\section{Scheme 28}

Refluxing of $\mathbf{2}$ with benzylidenemalononitrile in ethanol in presence of piperidine gave pyridone derivative $\mathbf{5 4} .^{41}$

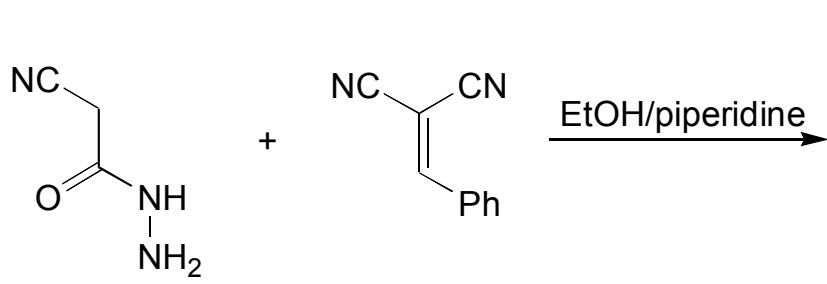

2<smiles>N#Cc1c(N)c(C#N)c(=O)n(N)c1-c1ccccc1</smiles>

54

\section{Scheme 29}

On heating 2 and arylidene of ethyl cyanoacetate in ethanol containing triethyl amine under reflux afforded diaminopyridine derivative $\mathbf{5 8}$ rather than aminopyridine derivative $\mathbf{5 6}{ }^{42,43}$ 


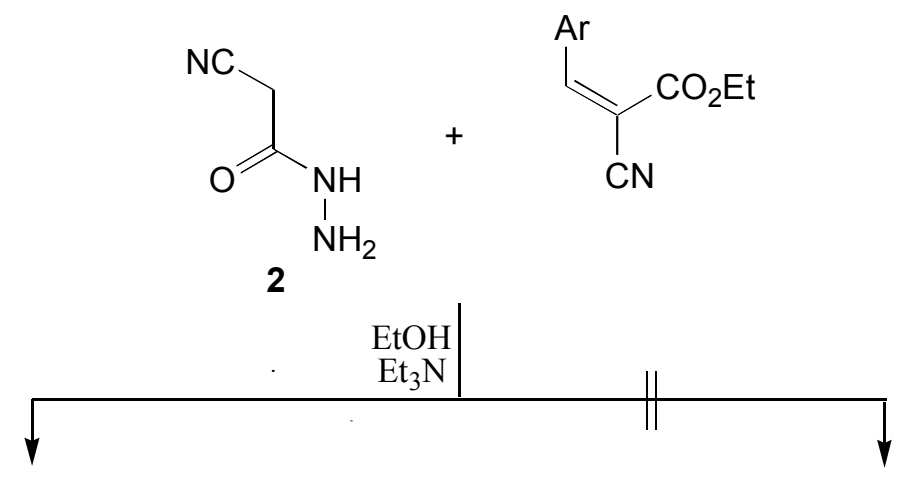<smiles>CCOC(=O)C1=C(N)N(N)C(=O)C(C#N)C1Br</smiles>

57<smiles>CC[14CH2][Te]c1c(C(=O)OCC)c(N)n(N)c(=O)c1C#N</smiles>

58<smiles>N#CC1=C(O)N(N)C(=O)C(C#N)C1Br</smiles>

55<smiles>CC[Y7](=O)c1c(C#N)c(O)n(N)c(=O)c1C#N</smiles>

56

\section{Scheme 30}

The one-pot reaction of $\mathbf{2}$ with aldehyde and an activated nitrile in ethanol containing a catalytic amount of piperidine yielded pyridine-2-one derivative $\mathbf{6 0}$. $^{44-46}$ 


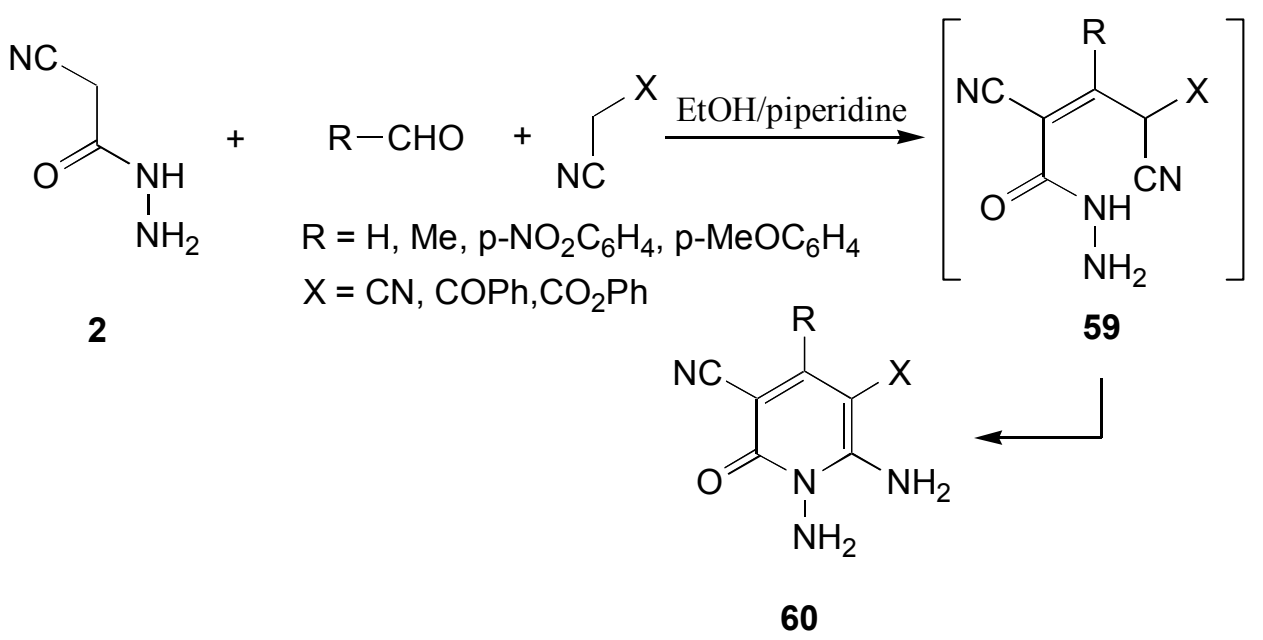

\section{Scheme 31}

Compound 2 reacted with (2E)-2-cyano- $N$-(4-methylphenyl)-3-phenylacrylamide in dry ethanol containing catalytic amount of piperidine under reflux to afford pyridine derivative $\mathbf{6 3}$ instead of compound 62 . $^{47}$

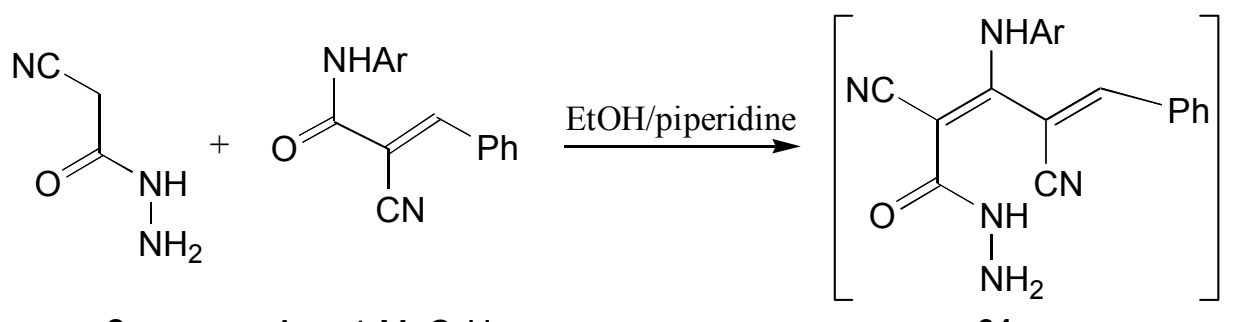

$2 \quad \mathrm{Ar}=4-\mathrm{MeC}_{6} \mathrm{H}_{4}$

61

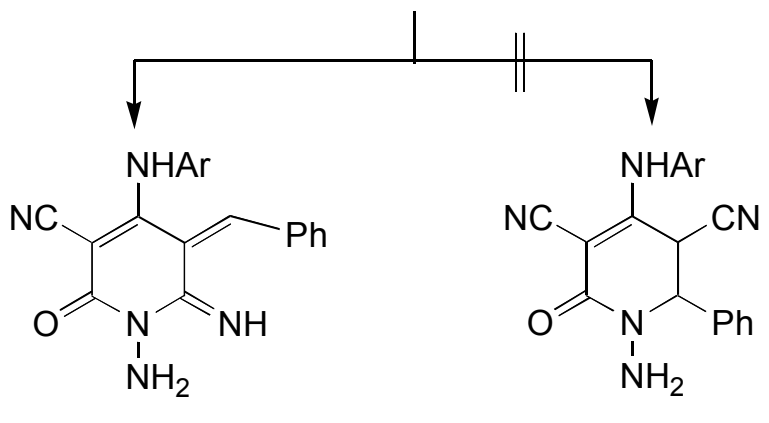

63

62

\section{Scheme 32}

Cyclocondensation of $\mathbf{2}$ with (4-methoxybenzylidene)malononitrile in ethanol in the presence of triethylamine afforded 1-aminopyridine derivative 64, which rearranged on heating 
in $95 \%$ aqueous ethanol/triethylamine to give 1,4-diamino-5-cyano-2-(4-methoxyphenyl)-6-oxo1,6-dihydropyridine-3-carboxylic acid $\mathbf{6 5} .^{48}$

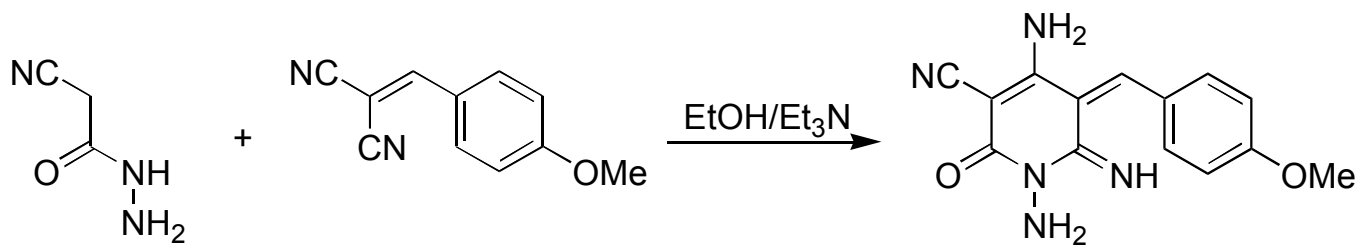

2<smiles>COc1ccc(-c2c(C(=O)O)c(N)c(C#N)c(=O)n2N)cc1</smiles>

64

\section{Scheme 33}

Martin and coworkers reinvestigated the cyclocondensation of $\mathbf{2}$ with (4methoxybenzylidene)malononitrile. They have found that prolonged heating lead only to the formation of 1,6-diamino-4-(4-methoxyphenyl)-3,5-dicyano-2-pyridone 66. The structure of compound 66 had been confirmed on the basis of chemical and spectroscopic evidence. ${ }^{49}$

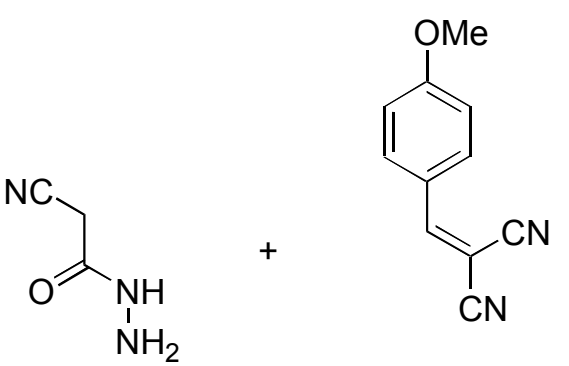

2

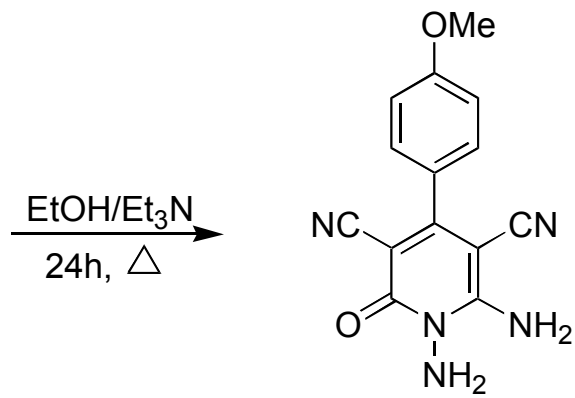

66

\section{Scheme 34}

Treatment of $\mathbf{2}$ with arylidene cyanothioacetamide in ethanol containing catalytic amount of piperidine yielded pyridine-thione derivatives $69 .{ }^{46}$ 
<smiles>[R]C=C(C#N)C(N)=S</smiles><smiles>N#CCC(=O)NN</smiles>

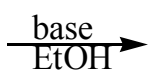

2<smiles>[R]C1C(C#N)C(=S)N=C(N)C1C(=O)NN</smiles>

67
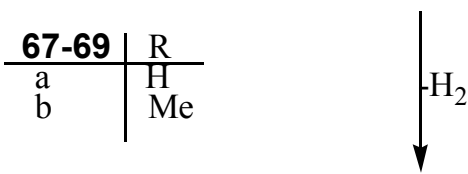<smiles>[R]c1c(C(=O)NN)c(N)[nH]c(=S)c1C#N</smiles>

69<smiles>[R]C1=C(C(=O)NN)C(N)=NC(=S)C1C#N</smiles>

68

\section{Scheme 35}

Reaction of cyanoaceto- $N$-arylsulfonylhydrazide 15a with 2-((thiophen-2-yl)methylene) malononitrile in ethanol containing a catalytic amount of piperidine furnished pyridin-2-one derivative $\mathbf{7 0} .^{50}$

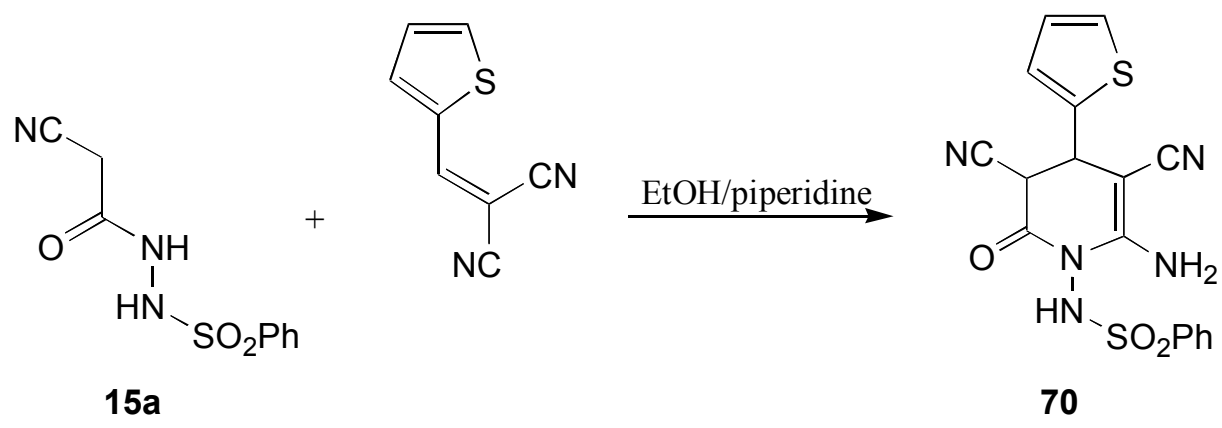

\section{Scheme 36}

Refluxing of cyanoaceto- $N$-arylsulfonylhydrazide 15 with arylidenecyanoacetate in presence of pyridine $^{51,52}$ afforded pyridone derivative 73 , while in the presence of ethanol containing a catalytic amount of piperidine ${ }^{51}$ afforded pyridine-2-one derivative $75 .{ }^{52}$ 
<smiles>CCOC(=O)/C(C#N)=C\CCCCC(C)C(C)C(Br)C(C)C(=O)NNS(=O)(=O)c1ccccc1</smiles>

15<smiles>CCCC[Al]C1C(C(=O)OCC)=C(N)N(NS(=O)(=O)c2ccccc2)C(=O)C1C#N</smiles>

74<smiles></smiles>

75 pyridine<smiles>C[Al]C1C(C#N)=C(O)N(NS(=O)(=O)c2ccccc2)C(=O)C1C#N</smiles>

72

$\mathrm{H}_{2}$

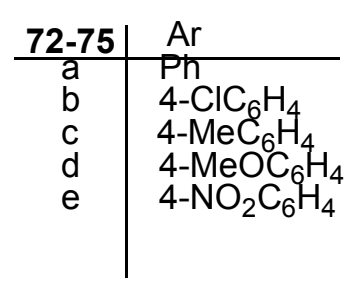<smiles>N#Cc1c(Br)c(C#N)c(=O)n(NS(=O)(=O)c2ccccc2)c1O</smiles>

73

\section{Scheme 37}

Substituted $N$-benzoylaminopyridone 76 was prepared by cyclocondensation of $N$ benzoylcyanoacetohydrazide $\mathbf{6 c}$ with ethyl acetoacetate in presence of sodium methoxide. ${ }^{52}$

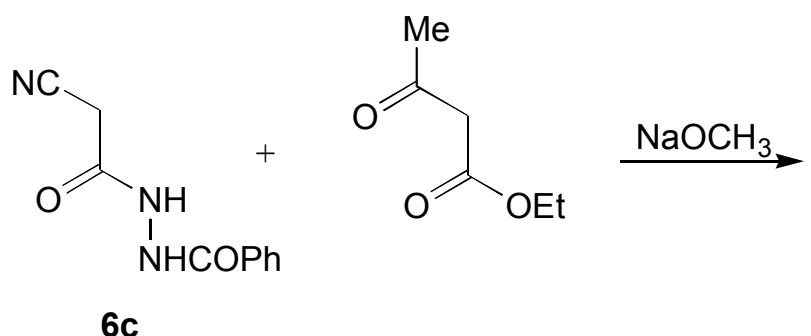<smiles>Cc1cc(O)n(NC(=O)c2ccccc2)c(=O)c1C#N</smiles>

76

\section{Scheme 38}


Cyclocondensation of 3-indolylidenecyanoacetohydrazide 77 with ethyl benzylidenecyanoacetate in the presence of a base gave the corresponding 4-phenyl-3,5-dicyano6-hydroxyl-1 $N$-(3-indolylidene) pyridin-2-ones $\mathbf{7 8} .^{53}$

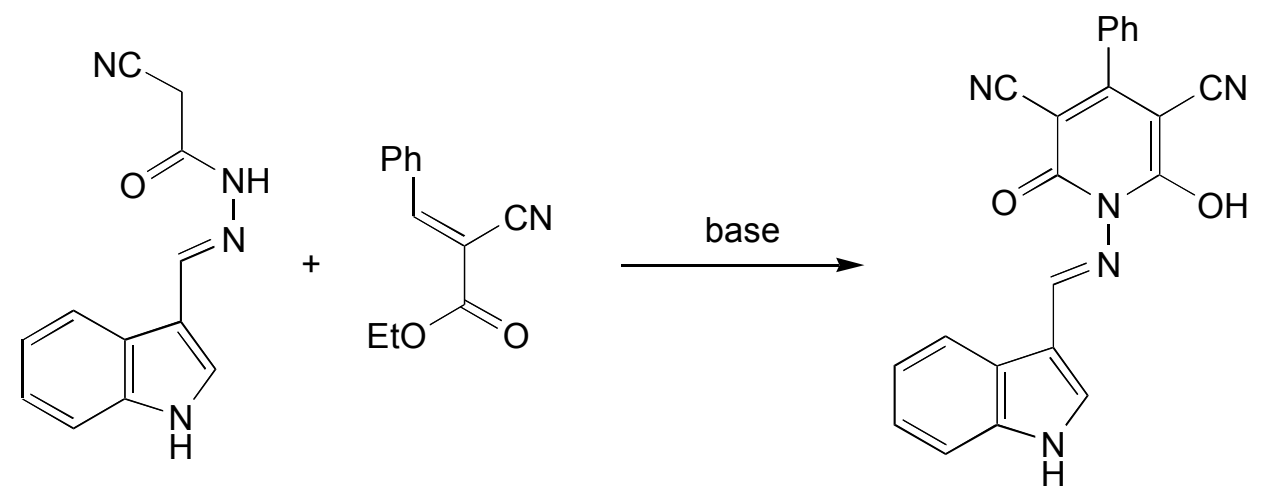

77

78

\section{Scheme 39}

On heating 2 with phenylhydrazono-3-oxobutyronitrile in refluxing ethanol containing a catalytic amount of triethyl amine yielded pyridine-2,6-dione derivative $79 .{ }^{54,55}$<smiles>CC(=O)C(C#N)=NN</smiles>

2<smiles>CCN(CC)CCO</smiles>

79

\section{Scheme 40}

Elzanate et al. have been reported a novel synthetic route to nitrosopyridinone derivative 80 via the reaction of oxime derivative of $\beta$-ketoester with $N$-benzoylcyanoacetohydrazide. ${ }^{56}$

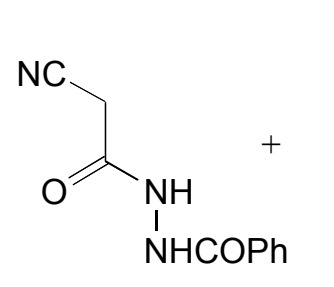

6c<smiles>CCOC(=O)/C(=N\O)C(C)=O</smiles><smiles>CC1CCCC1O</smiles><smiles>Cc1c([N+]#N)c(O)n(NC(=O)c2ccccc2)c(=O)c1C#N</smiles>

80

\section{Scheme 41}


The reaction of $\mathrm{N}$-cyanoacetylhydrazone of epiandrosterone $\mathbf{8 1}$ with malononitrile in ethanol in the presence of a catalytic amount of piperidine afforded pyridine-2-one derivative 82. ${ }^{57}$

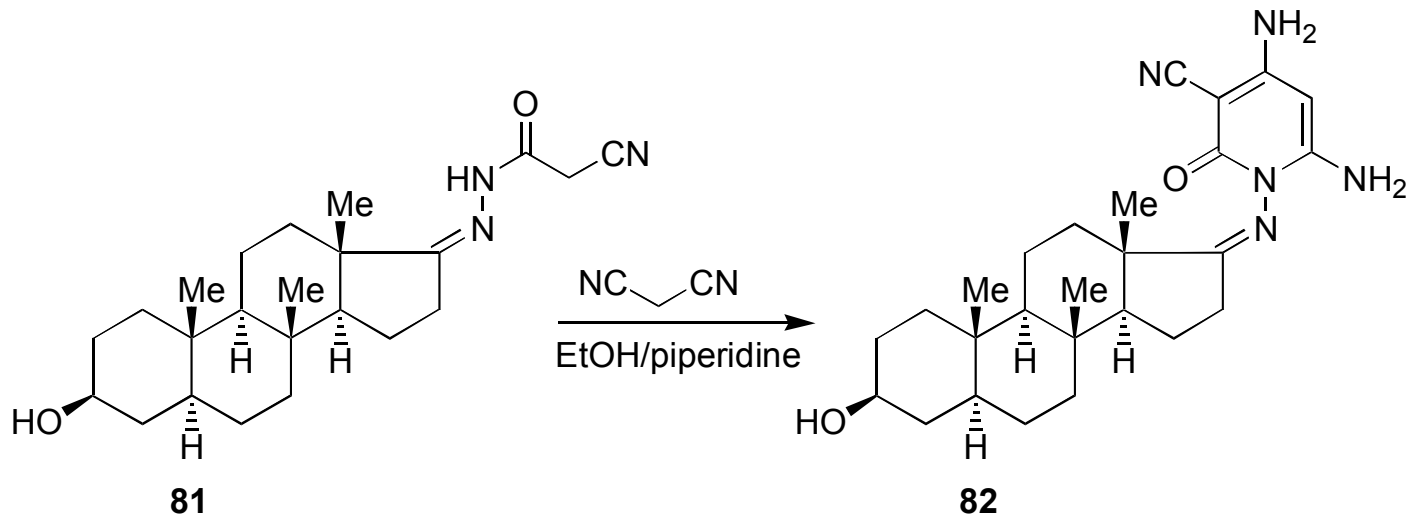

\section{Scheme 42}

Refluxing of 2 with 2-(4,5-dihydro-4-oxothiazol-2-yl)-3-phenylacrylonitrile in ethanol containing catalytic amount of piperidine gave 5-amino-8-cyano-3-oxo-7-phenyl-2,3-dihydro$7 H$-[1,3]thiazolo[3,2-a]pyridine-6-carboxylic acid $\mathbf{8 3} .^{41}$<smiles>CC(=O)N=C(C)C(C#N)=Cc1ccccc1</smiles><smiles>CCO[C@H](C)[C@H]1CCCCC1c1ccccc1</smiles>

83

\section{Scheme 43}

Cyclocondensation of $\mathbf{2}$ with 5-chloro-3-methyl-1-phenyl-1H-pyrazole-4-carbaldehyde yielded 7-amino-3-methyl-6-oxo-1-phenyl-6,7-dihydro-1H-pyrazolo[3,4- $b]$ pyridine-5carbonitrile $84^{58}$ 
<smiles>Cc1nn(-c2ccccc2)c(Cl)c1C=O</smiles>

2

84

\section{Scheme 44}

Condensation of cyanoacetic acid hydrazones 85 with 1-aminoanthraquinone under Vilsmeier reaction conditions afforded 3-azabenzanthrone derivatives 86 . $^{59}$

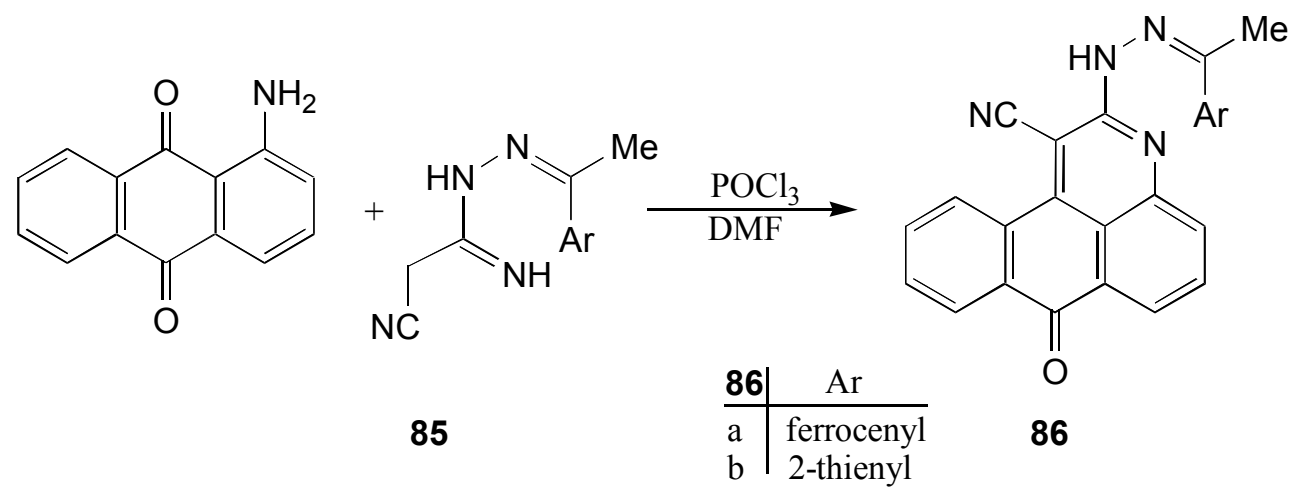

\section{Scheme 45}

Cyclocondensation of $\mathbf{2}$ with (2E)-2-(1H-benzimidazol-2-yl)-3-arylacrylonitrile under reflux in the presence of a base gave 1-amino-3-aryl-4-cyanopyrido[1,2-a]benzimidazole-2carbohydrazide $87 .^{60}$

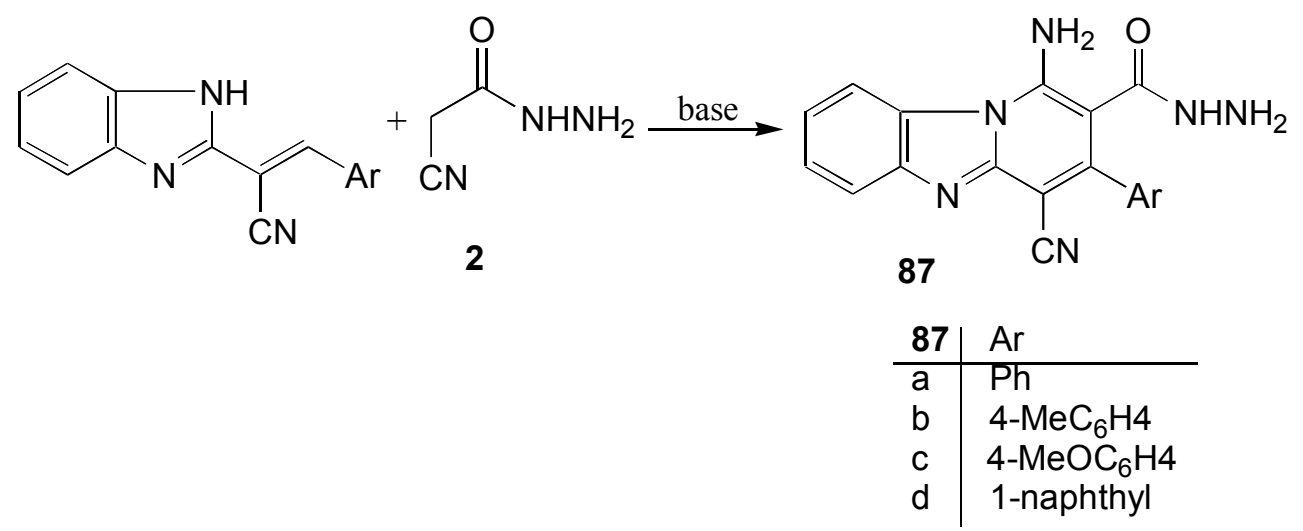

\section{Scheme 46}


The reaction of 2 with $\alpha, \beta$-unsaturated ketones in the presence of a base gave pyrazolo[3,4b]pyridine-3-one derivative $\mathbf{8 9} .^{61}$<smiles>CC(C=CC(=O)Br)=C(Br)Br</smiles>

2<smiles>CNC(=O)C(C#N)C(Br)CC(=O)Br</smiles>

88<smiles>O=C1NN=C2N=C([Al])CC(Br)C12</smiles>

89

\section{Scheme 47}

Pyrazolopyridines $\mathbf{9 0}$ were obtained via cyclocondensation of $\beta$-ketoaldehyde with $\mathbf{2}$ in alkaline medium. ${ }^{62}$

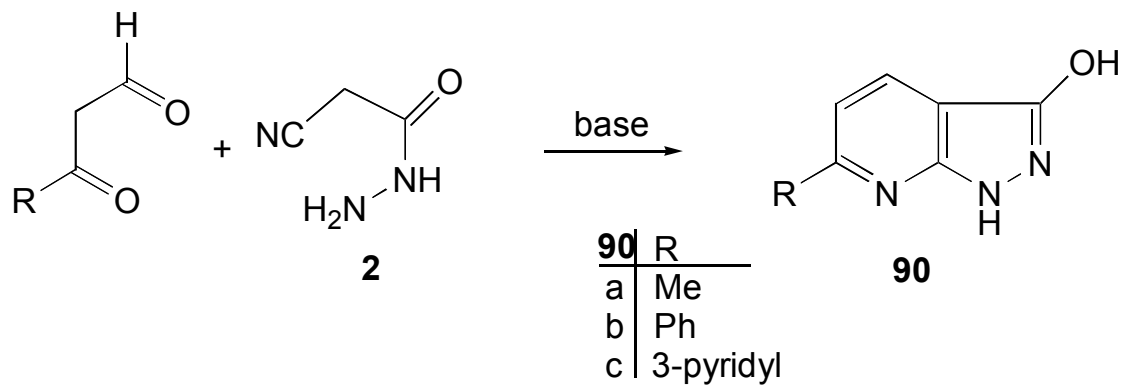

\section{Scheme 48}

Pyrazolo[3,4-b]pyridine derivative $\mathbf{9 2}$ was prepared via the reaction of $\alpha$ benzoylcinnamonitrile with $N$-acetyl cyanoacetohydrazide $91 .^{63}$

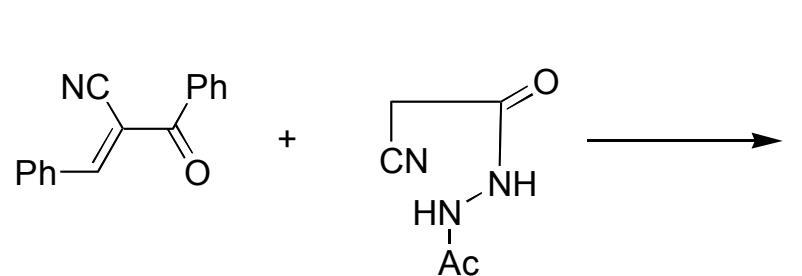

91<smiles>N#Cc1c(-c2ccccc2)nc2[nH][nH]c(=O)c2c1-c1ccccc1</smiles>

92

\section{Scheme 49}

Cyclocondensation of $\mathbf{2}$ with $\beta$-aminocrotononitrile in acidic medium yielded pyrazolo[3,4-b]pyridine derivative $\mathbf{9 3} .^{64}$ 


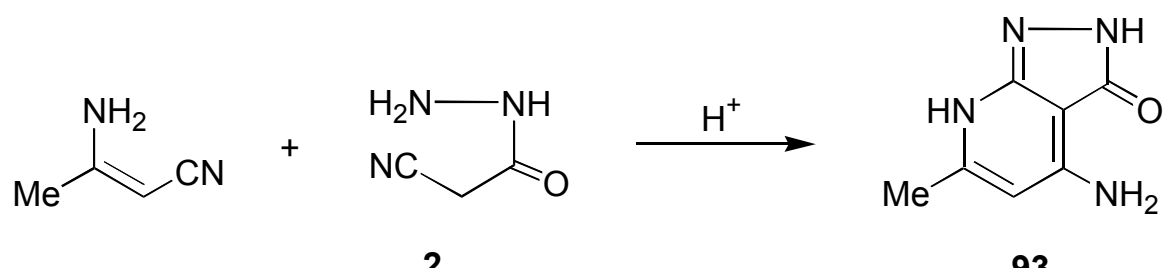

2

93

\section{Scheme 50}

The reaction of 2 with 3-acetylcoumarin in ethanol containing a catalytic amount of piperidine under reflux afforded 5-methyl-2,11c-dihydrochromeno[4,3-d]pyrazolo[3,4b] pyridine-1,6-dione $95{ }^{65}$<smiles>CC(=O)c1cc2ccccc2oc1=O</smiles><smiles>CCN(C)CO</smiles><smiles>CC(=O)c1c(C2C(=O)NN=C2N)c2ccccc2oc1=O</smiles>

95

\section{Scheme 51}

Reaction of 2 with different aromatic aldehydes in ethanol under reflux afforded $1 N$ arylmethylidene-2-cyanoacetohydrazides 96 that were treated with benzylidenemalononitrile to give $[1,2,4]$ triazolo[1,5-a]pyridin-5(3H)-one derivatives $97 .^{66}$ 


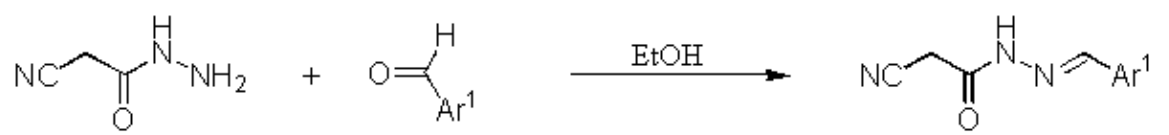

2

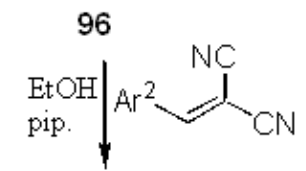

\begin{tabular}{c|cl}
$96-97$ & $\mathrm{Ar}^{2}$ & $\mathrm{Ar}^{1}$ \\
\hline $\mathrm{a}$ & $\mathrm{Ph}$ & $\mathrm{Ph}$ \\
$\mathrm{b}$ & $\mathrm{Ph}$ & $4-\mathrm{MeOC}_{6} \mathrm{H}_{4}$ \\
$\mathrm{c}$ & $\mathrm{Ph}$ & $4-\mathrm{ClC}_{6} \mathrm{H}_{4}$
\end{tabular}<smiles>N#Cc1c(Br)c(C#N)c2nc([Al])[nH]n2c1=O</smiles>

97

\section{Scheme 52}

$[1,2,4]$ Triazolo[1,5-a]pyridin-5(1H)-one derivatives 99 were prepared in one pot reaction in excellent yields by the reaction of $\mathbf{2}$ with malononitrile and an aromatic aldehyde. ${ }^{67}$

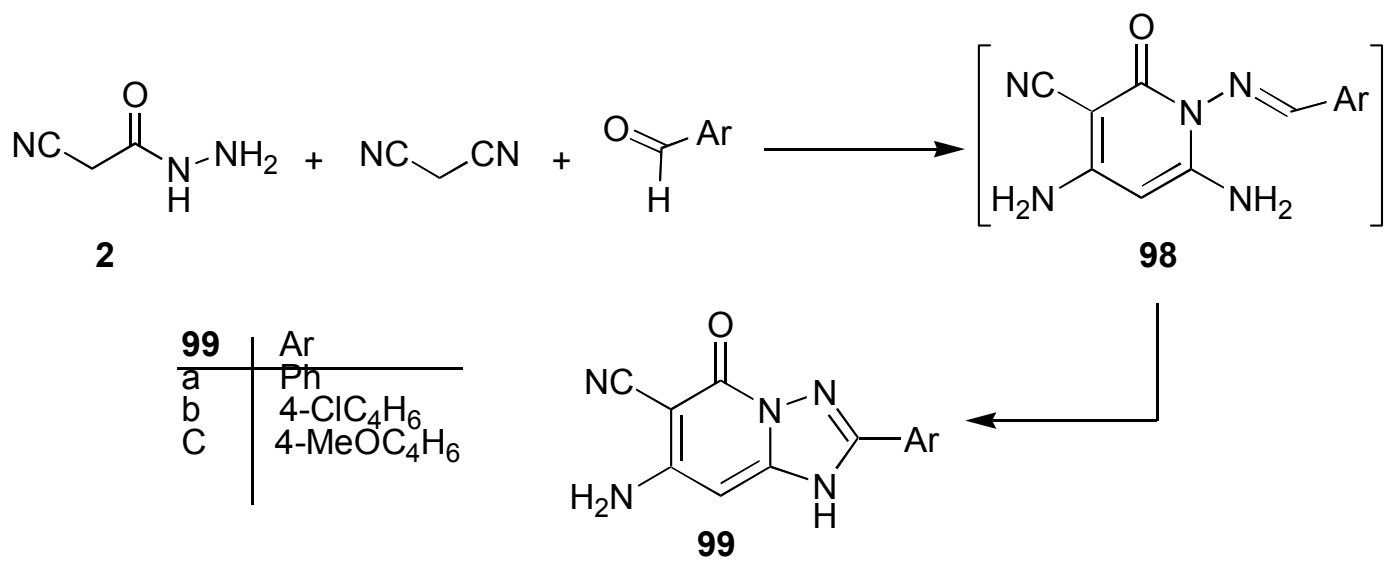

\section{Scheme 53}

Martin and coworkers have reported that an unexpected reaction between $N$-acetyl cyanoacetohydrazide 91 and $\alpha$-cyanocinnamonitrile in ethanol containing catalytic amount of piperidine afforded a novel 2-methyl-5-oxo-7-phenyl-1,5-dihydro[1,2,4]triazolo[1,5-a]pyridine6,8-dicarbonitrile $\mathbf{1 0 0} .^{68}$ 


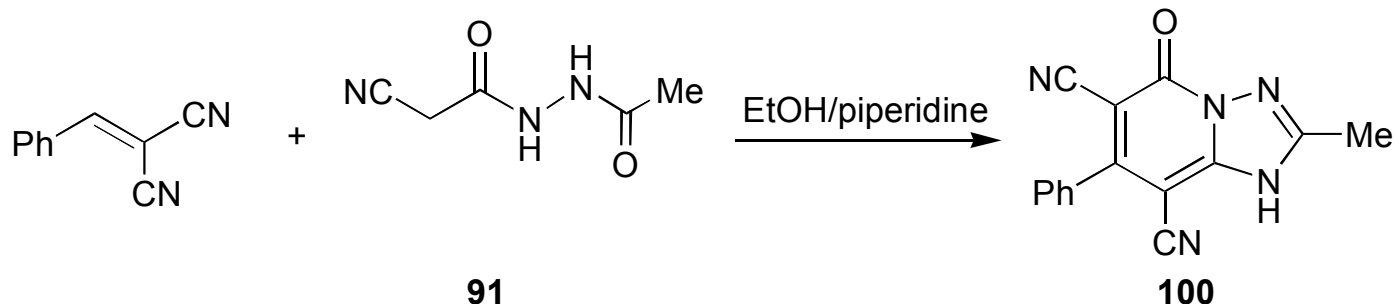

\section{Scheme 54}

Refluxing of hydrazone derivative 11d and appropriate arylidenes of activated nitriles in ethanolic piperidine yielded spiro[cyclohexane-1,2 $2^{\prime}[1,2,4]$ triazolo[1,5- $a$ ]pyridine $]-5^{`}-\left(1^{`} H\right)$-one derivatives 102. ${ }^{24,69}$

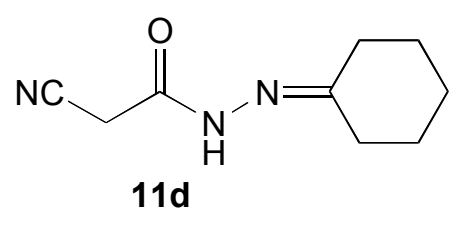

$+$<smiles>[X]/C(C#N)=C/[Bi]</smiles>

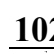

10

$\mathrm{a}$

b

c

d

f

91

100

\section{Scheme 55}

On the other hand, 3-indolylidenecyanoacetohydrazide 77 condensed with different arylidenemalononitriles in presence of a base to give 7-aryl-6,8-dicyano-2-(3indolyl) $[1,2,4]$ triazolo[1,5-a]-pyridin-5-ones $103 .{ }^{53}$ 


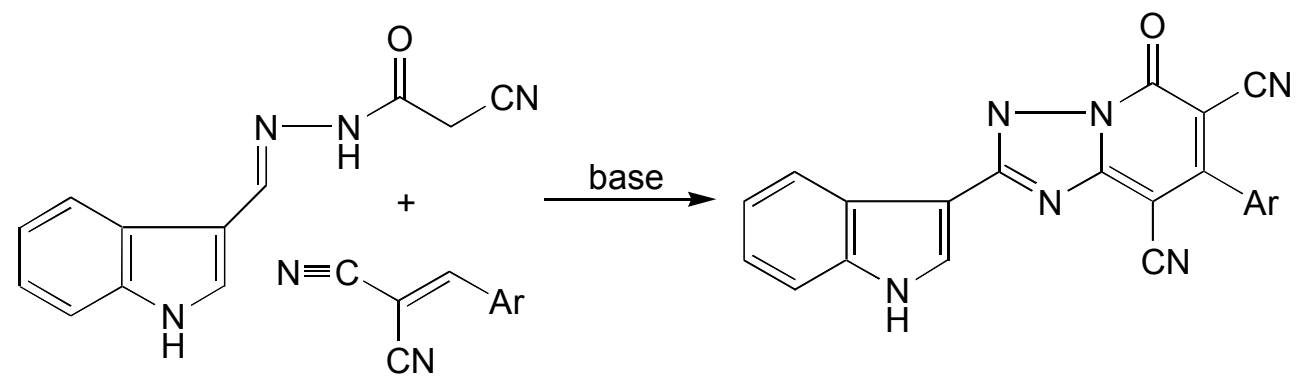

78

103

\section{Scheme 56}

When anthranilonitrile was fused on an oil bath at $170{ }^{\circ} \mathrm{C}$ with different $N$-arylidenes of cyanoacetohydrazide 96 in presence of triethyl amine, it afforded triazolo[4,3-a]quinoline derivatives 106. Compounds 106 are assumed to be formed by the initial Thorpe-Ziegler addition $^{65}$ of the methylene group 96 to the $\mathrm{CN}$ group of anthranilonitrile to afford the acyclic intermediates 104, followed by loss of a water molecule to afford the acyclic intermediates $\mathbf{1 0 5}$, which in turn undergo a further cyclization via addition of the $\mathrm{NH}$ to the activated $\mathrm{C}=\mathrm{N}$ to give the final products $\mathbf{1 0 6} .^{70}$<smiles>CC(C)[N+](C)(C)C(C)(C)C(C)(C)C</smiles>

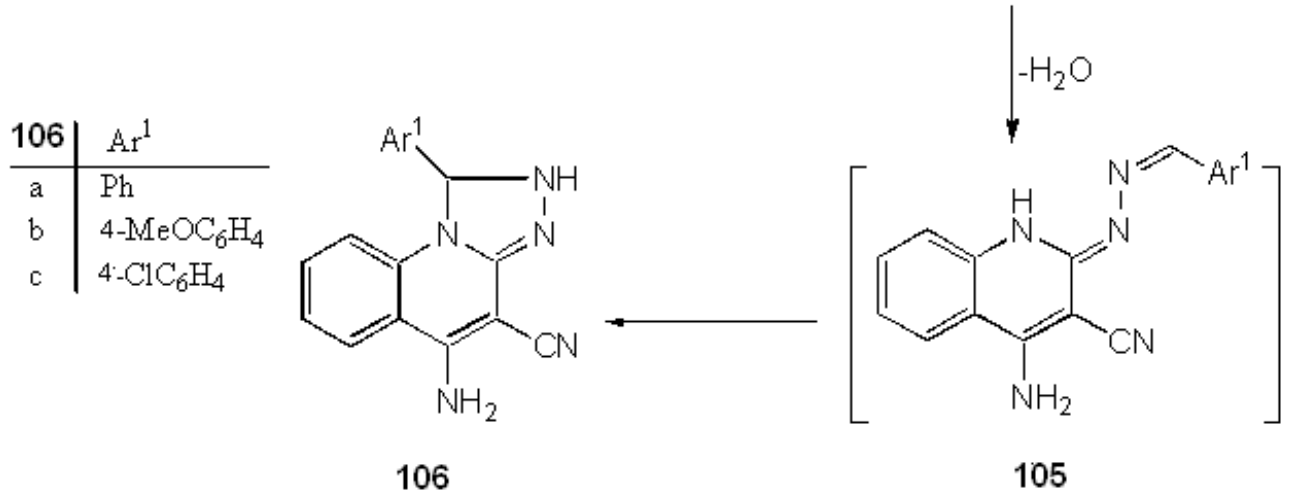

\section{Scheme 57}




\subsubsection{Pyrans and their fused derivatives}

Refluxing of hydrazone derivative 11d and salicylaldehyde in ethanol containing a catalytic amount of sodium hydroxide afforded $N^{\prime}$-cyclohexylidene-2-imino-4-oxochromane-3carbohydrazide $107 .^{71}$

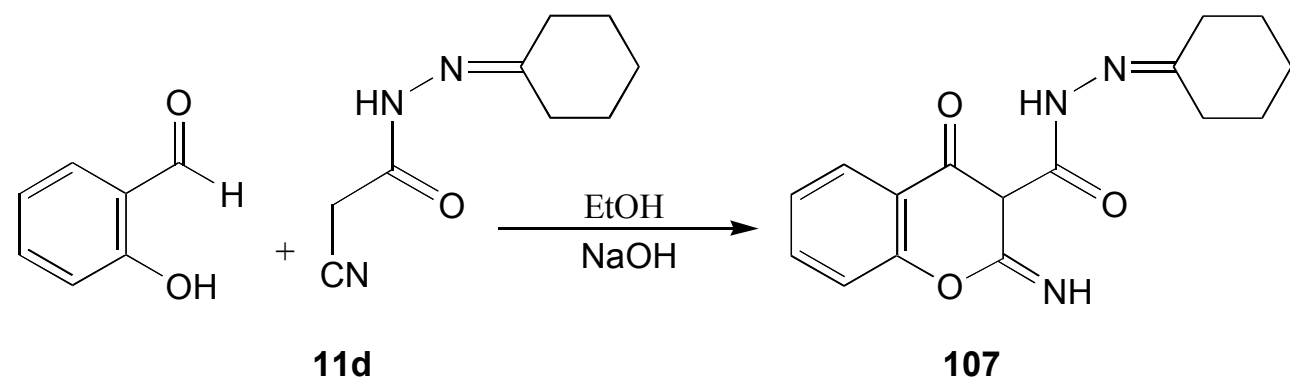

\section{Scheme 58}

3-Methyl-6-oxo-4-phenyl-1,6-dihydropyran[2,3-c]pyrazole-5-carbonitrile $\mathbf{1 0 8}$ was prepared via cyclocondensation of $\mathbf{2}$ with 4-benzylidene-3-methyl-2-pyrazolin-5-one. ${ }^{72}$<smiles>N#CCC(=O)NN</smiles>

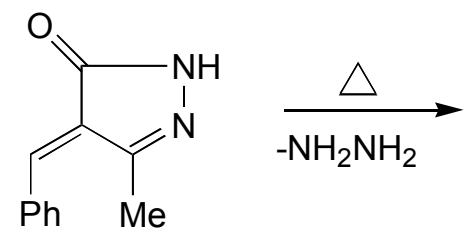

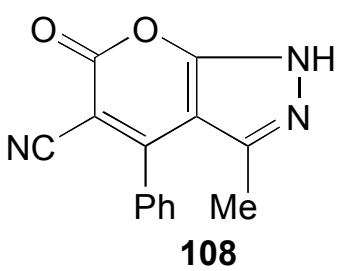

\section{Scheme 59}

Refluxing of 2 with pyrazolinone in ethanol in the presence of piperidine gave 6-amino-3methyl-4-phenyl-1,4-dihydropyran[2,3-c]pyrazole-5-carbohydrazide $109 .{ }^{41}$<smiles>N#CCC(=O)NN</smiles>

\section{Scheme 60}


Cyclocondensation of $\mathbf{2}$ with benzofuranyl derivatives under Claisen-Schmidt reaction yielded 4-aryl-6-(6-hydroxy-2,3-diphenyl-1-benzofuran-5-yl)-2-imino-3,4-dihydro-5-phenyl-2 $\mathrm{H}$ pyran-3-carbohydrazide $110{ }^{73}$<smiles>CCCCCCCCCCCC(=O)c1cc2c(-c3ccccc3)c(-c3ccccc3)oc2cc1O</smiles>

$$
\begin{array}{r|l}
110 & \mathrm{Ar} \\
\hline \mathrm{a} & \mathrm{p}-\mathrm{MeC}_{6} \mathrm{H}_{4} \\
\mathrm{~b} & \mathrm{p}-\mathrm{ClC}_{6} \mathrm{H}_{4}
\end{array}
$$<smiles>N=C1OC(c2cc3c(-c4ccccc4)c(-c4ccccc4)oc3cc2O)=C(P)C([Al])C1C(=O)NN</smiles>

110

\section{Scheme 61}

Reaction of 2 with benzopyranone in ethanol containing a catalytic amount of triethyl amine under reflux afforded 2-imino-5-methoxy-8-methyl-6-oxo-4-(2-oxo-2-phenylethyl)-3,4dihydro- $2 H, 6 H$-pyrano[3,2-g]chromene-3-carbohydrazide $111 .^{74}$

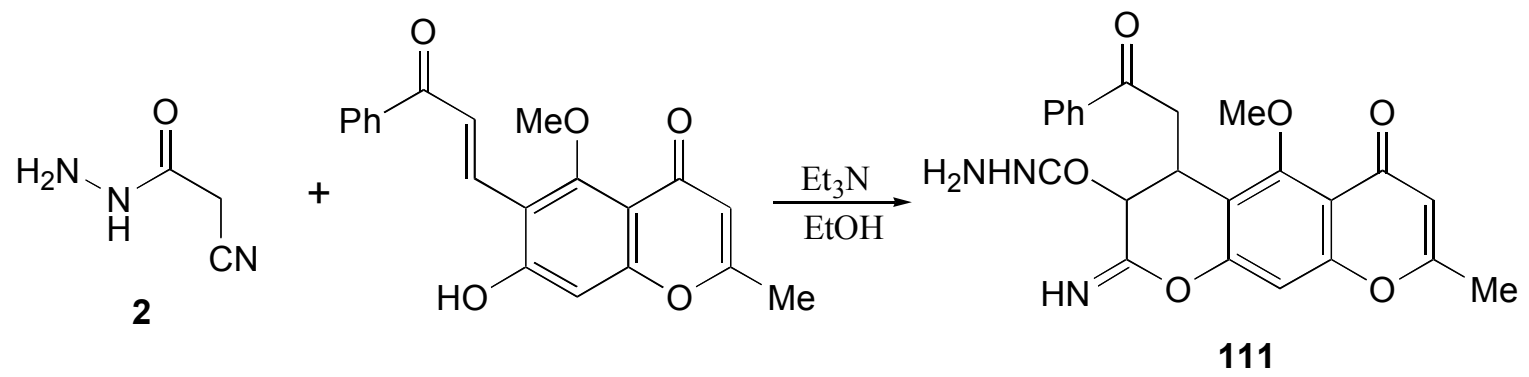

\section{Scheme 62}

Reaction of bisdithiolobenzoquinone with 2 in a 1:2 molar ratio in alkaline medium gave dispiro[4H-pyran-4,2 '-[1,3]dithiolo[4,5-f][1,3]benzodithiole-6 '4 ' '-[4H]pyran]-3,3 ' dicarbonitrile derivative 112. ${ }^{75}$ 


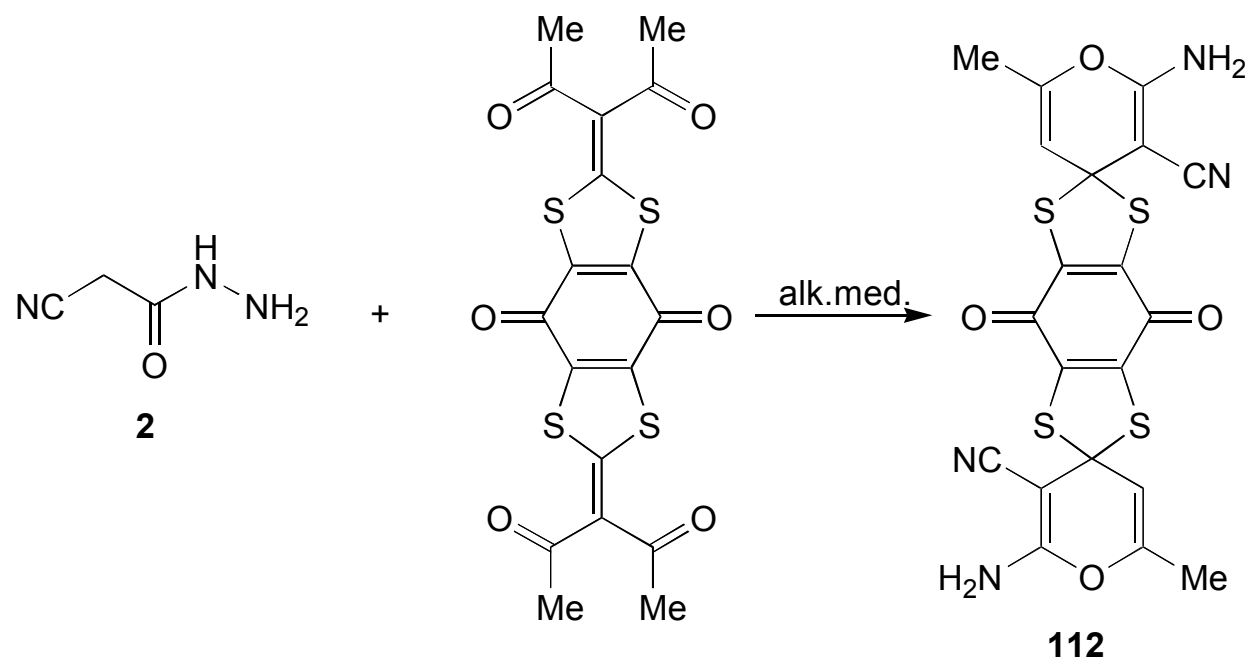

\section{Scheme 63}

\subsubsection{Thiopyran}

The reaction of 2 with benzalcyanothioacetamide in ethanol containing a catalytic amount of triethyl amine gave thiopyran derivative $113 .^{76}$<smiles>CC(CC(=O)C#N)NNNC(=O)CC(C)(C)C</smiles>

\section{Scheme 64}

\subsection{Synthesis of Six-Membered Ring with Two Heteroatoms}

\subsubsection{Pyridazines and their fused derivatives}

Reaction of 2 with biacetyl in ethanol at room temperature yielded pyridazin-3-one derivative 115. $^{77}$ 


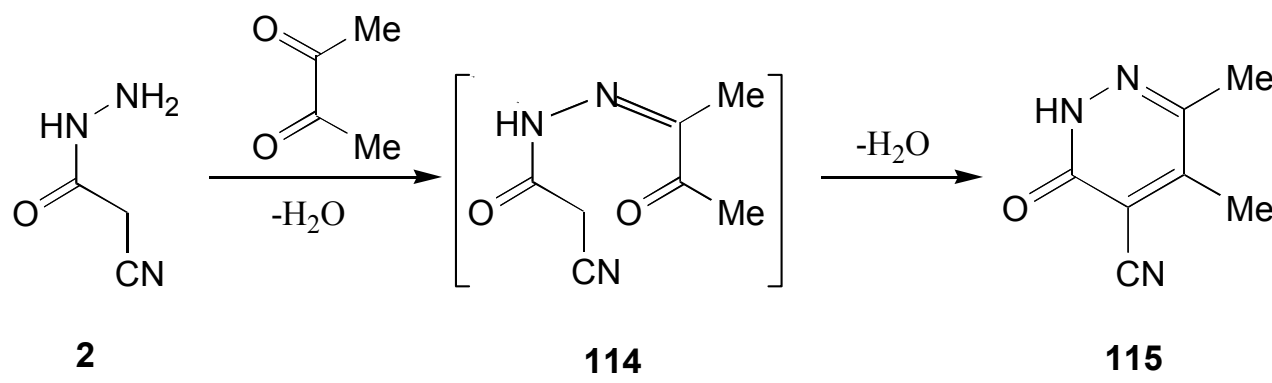

\section{Scheme 65}

Refluxing of $\mathbf{2}$ with aceanthraquinone in acetic acid gave $\mathbf{1 1 6}$ that transformed into aceanthryleno[1,2-c]pyridazine derivative 117 when treated with potassium hydroxide. ${ }^{78}$<smiles></smiles>

\section{Scheme 66}

Cyclocondensation of $\alpha$-(ethoxymethylene)-2,3,4,5-tetrafluoro- $\beta$-oxobenzenepropanoic acid ethyl ester with 2 led to the formation of fluorinated 1,3,4-oxadiazino[6,5,4-i,j]quinolines 118. ${ }^{79}$<smiles>CCOC(=O)CC(=O)c1cc(F)c(F)c(F)c1F</smiles>

\section{Scheme 67}


The reaction of 2 with 2-phenyl-1,1,3-tricyano-3-bromopropene in a basic medium gave the nonisolable acyclic intermediate 119, which underwent cyclization via the addition of the active methylene to the $\mathrm{CN}$ group to afford the pyrrolo[1,2-b]pyridazine derivative $\mathbf{1 2 0} .^{80}$

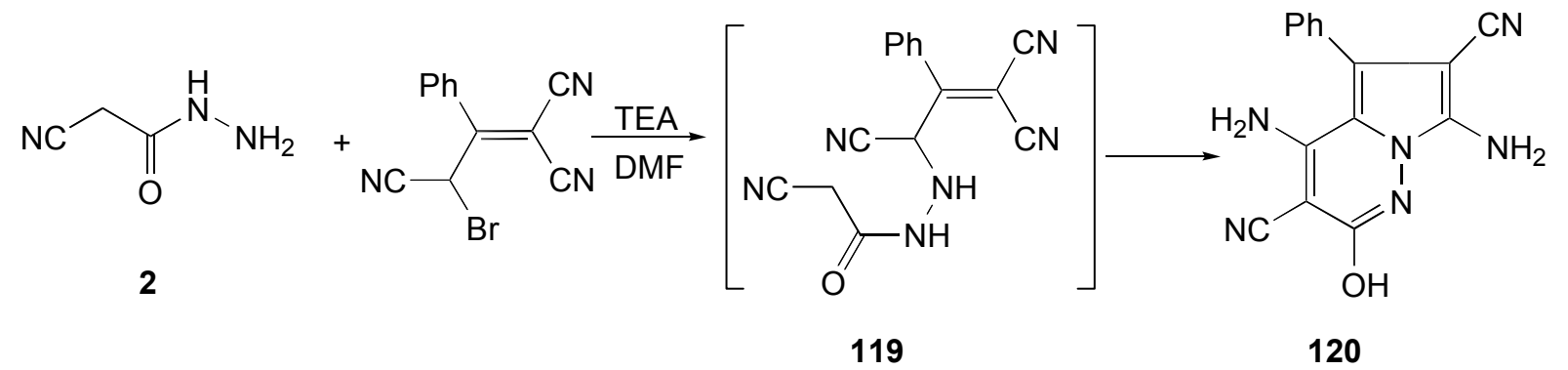

\section{Scheme 68}

\subsubsection{Pyrimidine and their fused derivatives}

Barbituric acid derivative 121 could be obtained by the reaction of chlorocarbonylisocyanate with 2. $^{81}$<smiles>N#CCC(=O)NN</smiles>

2<smiles>O=C=NC(=O)Cl</smiles>

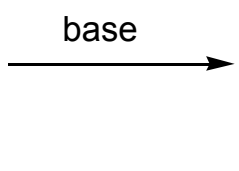

121

\section{Scheme 69}

Mohareb and coworkers reported that the reaction of $N$-benzylidene of cyanoacetohydrazide 97 a with ethyl cyanoacetate afforded pyrimidine derivative $122 .{ }^{82}$

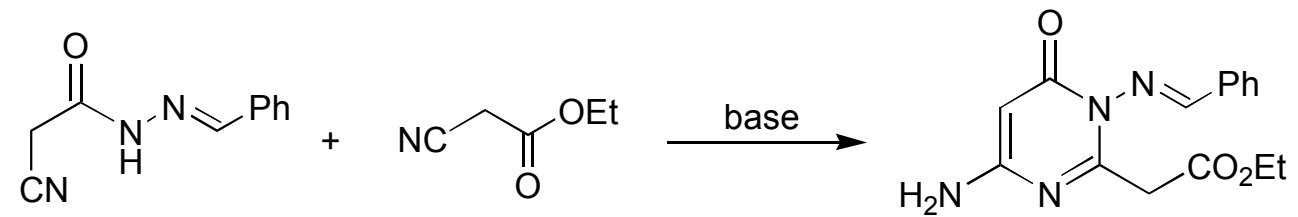

Scheme 70 
Cinnamoyl isothiocyanate reacts with $\mathbf{2}$ to give the corresponding cinnamoyl thiourea $\mathbf{1 2 3}$ which undergo cyclization in refluxing sodium ethoxide solution to give the corresponding 1-(5oxo-4,5-dihydro-1H-pyrazol-3-yl-)-6-phenyl-2-thioxotetrahydropyrimidin-4(1H)-one $124 .^{83}$<smiles>CC(C)(C)C(=O)CNNC(=O)/C=C/c1ccccc1</smiles><smiles>CCON(C)CC1CC(=O)NN=C1N1C(=S)NC(=O)CC1c1ccccc1</smiles>

124

\section{Scheme 71}

Abdel Rahman et al. reported that treatment of 3-chloro-5,6-diphenyl-1,2,4-triazine with 2 in pyridine gave compound $\mathbf{1 2 5}$ which underwent dehydrocyclization by boiling in acetic acid containing catalytic amount of anhydrous sodium acetate to give 6-methyl-8-oxo-2,3-diphenyl$8 H$-pyrimido[1,6- $b][1,2,4]$ triazine-9-carbonitrile $\mathbf{1 2 6} .^{84}$<smiles>Clc1nnc(-c2ccccc2)c(-c2ccccc2)n1</smiles><smiles>N#CCC(=O)NN</smiles>

2<smiles>Cc1nc(=O)c(C#N)c2nc(-c3ccccc3)c(-c3ccccc3)nn12</smiles>

126<smiles></smiles><smiles>N#CC(C(=O)NN)c1nnc(-c2ccccc2)c(-c2ccccc2)n1</smiles>

125

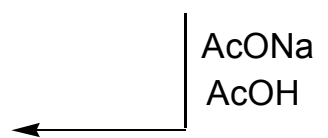

\section{Scheme 72}

The reaction of $\mathbf{2}$ with arylhydrazonomalononitrile in ethanol under reflux afforded pyrazolo[1,5-a]pyrimidine derivative $\mathbf{1 3 0}^{85}$ 


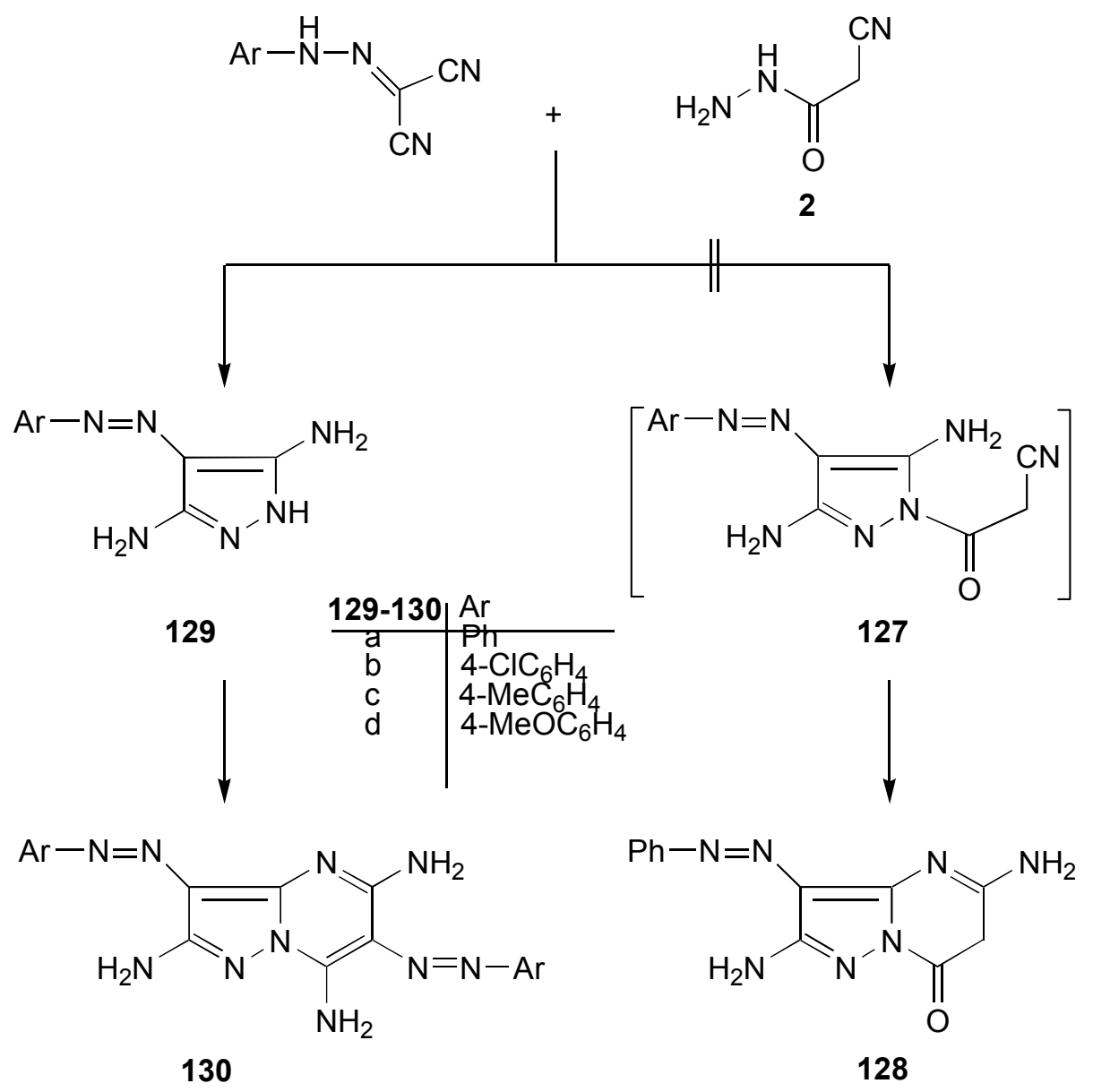

\section{Scheme 73}

4-Amino-5-arylidenehydrazinocarbonylthiazole-2(3H)-thiones 131 were prepared by the reaction of $\mathrm{N}$-arylidene cyanoacetic acid hydrazides 96 with sulphur and phenyl isothiocyanate in the presence of triethyl amine. These compounds were cyclized by acetic anhydride to give the corresponding thiazolo[4,5-d]pyrimidines $132 .^{86}$<smiles>N#CCC(=O)N/N=C\[Al]</smiles>

97<smiles></smiles>

131

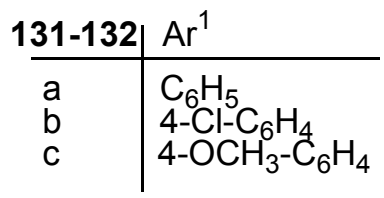

\section{Scheme 74}


Treatment of 2 with pentane-2,4-dione in ethanol in the presence of acetic acid led to the formation of 5,7-dimethylpyrazolo[1,5-a]pyrimidin-2-ol 133. ${ }^{87}$<smiles>CC(=O)CC(C)=O</smiles><smiles>C1CCCCC1</smiles><smiles>N#CCC(=O)NN</smiles>

2

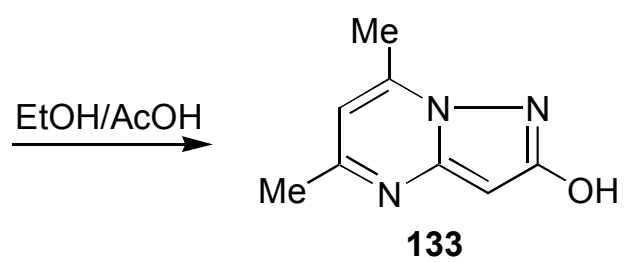

133

\section{Scheme 75}

2-(2-Bromo-1-phenyl-2-thiocyanatoethylidene)malononitrile reacts with 2 to afford $4 H$ pyrrolo[1 $\left.1^{`} 2^{`}: 4,5\right][1,3,4]$ thiadiazolo[3,2-a]pyrimidin-4-one derivative $134 .^{88}$

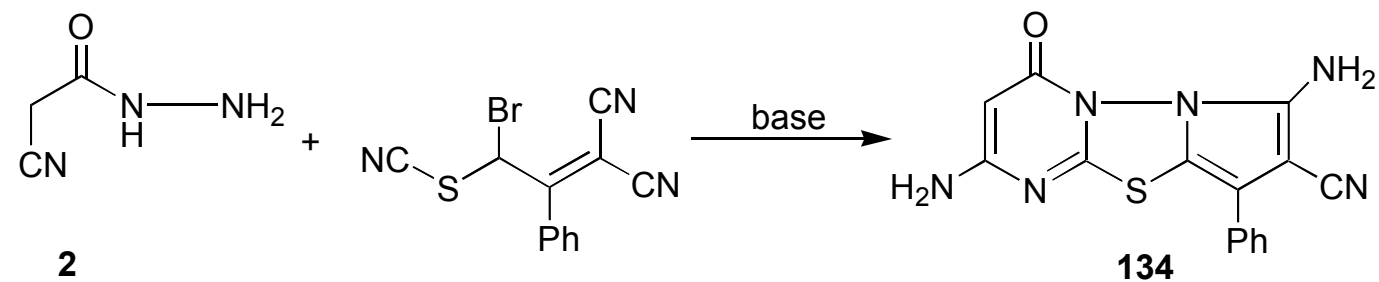

\section{Scheme 76}

Heating of cyclopentylidene hydrazide of cyanoacetic acid 11c with salicylaldehyde in presence of a base afforded $3 H$-chromeno[2,3- $d]$ pyrimidin-4(5H)-one derivatives $137 .{ }^{89}$

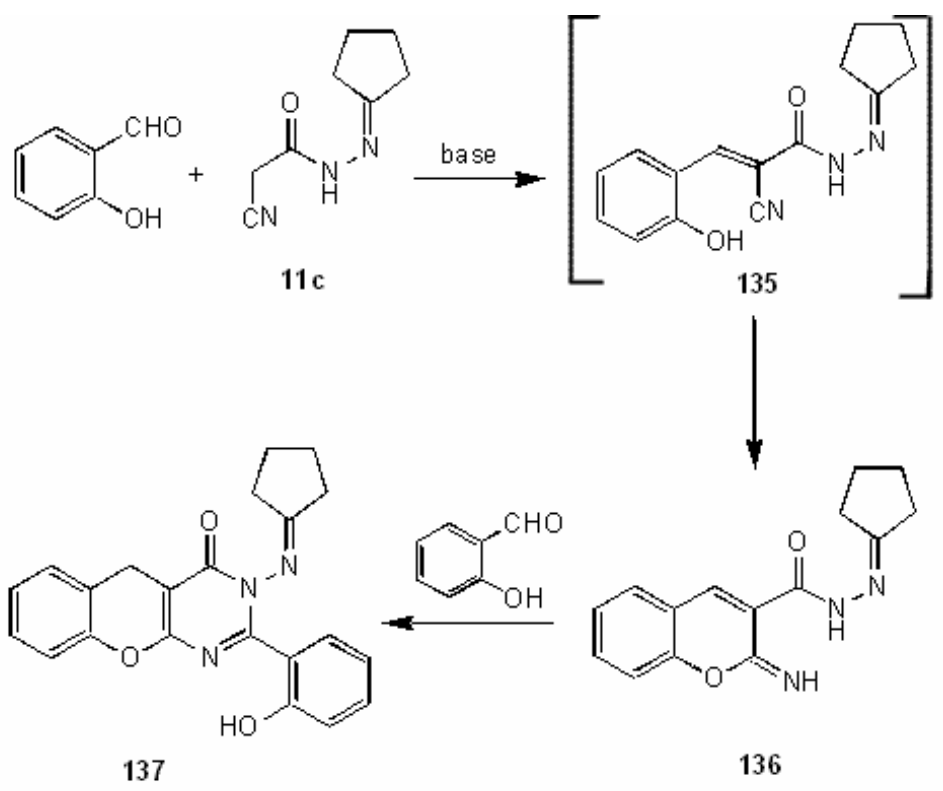

\section{Scheme 77}




\subsection{Synthesis of Six-Membered Ring with Three Heteroatoms}

\subsubsection{Thiadiazine}

The reaction of 1-cyanoceto-4-phenylthiosemicarbazide 37 with ethyl bromoacetate in DMF and in the presence of anhydrous potassium carbonate at room temperature gave 1,3,4-thiadiazine derivative $138 .^{33}$<smiles>N#CCC(=O)NNC(=S)Nc1ccccc1</smiles>

37<smiles>CCOC(=O)CBr</smiles>

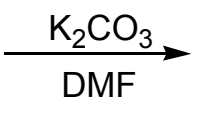<smiles>N#CCC(=O)N1N=C(Nc2ccccc2)SCC1=O</smiles>

138

\section{Scheme 78}

\subsubsection{Triazine}

Nucleophilic addition reaction of 3-thiophen-2-yl-acryloylisothiocyanate with $\mathbf{2}$ afforded thiocarbamoyl derivative $\mathbf{1 3 9}$ which gave pyrazolo[1,5-a][1,3,5]triazine derivative $\mathbf{1 4 0}$ on treatment with $5 \%$ potassium hydroxide..$^{90}$

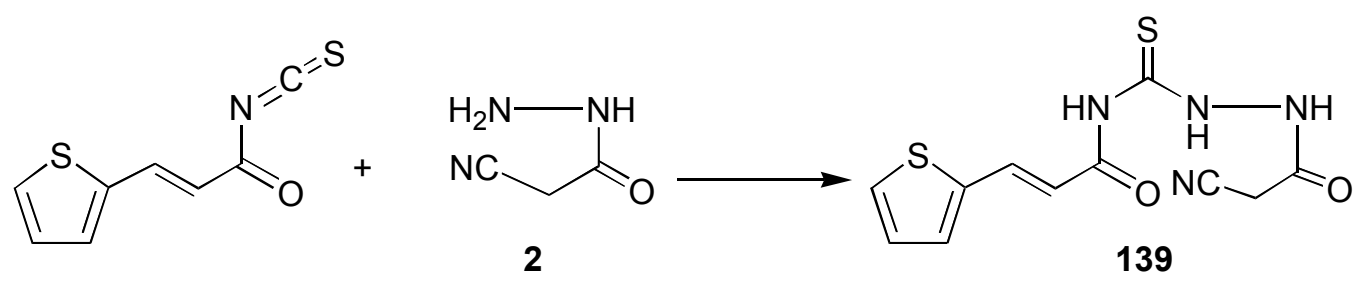<smiles>OCCCCCCCCCCCc1nc(S)n2nc(O)cc2n1</smiles>

\section{Scheme 79}

\section{Conclusions}

The data considered in this review clearly demonstrate the high synthetic potential of cyanoacetic acid hydrazide. Many biologically active heterocyclic compounds have been 
obtained based on these reagents. ${ }^{1-10}$ This suggests that cyanoacetic acid hydrazide can be particularly promising synthons in combinatorial synthesis of functionalized carbo- and heterocyclic compounds used in the design of novel highly effective pharmaceuticals with a broad spectrum of bioresponses. The great interest of chemists in such reagents is confirmed by the facts that more than 80 articles of 90 cited in this review are dated in the last two decades, along with a multitude of patents.

\section{References}

1. Elnagdi, M. H.; Elmoghayar, M. R. H.; Elgemeie, G. E. H. Synthesis 1984, 1.

2. Gaber, A. M.; El-Gaby, M. S. A.; El-Dean, A. M. K.; Eyada, H. A.; Al-Kamali, A. S. N. J. Chin. Chem. Soc. 2004, 51, 1325.

3. Elagamey, A. G. A.; El-Taweel, F. M.; Khodeir, M. N. M.; Elnagdi, M. H. Bull. Chem. Soc. Jpn. 1993, 66, 464.

4. Hussein, A. H. M. Heteroatom Chem. 1996, 7, 2.

5. Elnagdi, M. H.; Erian, A. W. Arch. Pharm. 1991, 324, 853.

6. Gilman, A. G.; Goodman, L. S. Pharmaceutical Basis of Therapeutics. Macmillan: New York, 1985; p 1109.

7. Cosales, M. J.; Kleschick, W. A.; Her, R. J.; Wiemer, M. R. US Patent 1998, 792, 587; Chem. Abstr. 1998, 128, 67792k.

8. De Marinis, R. M.; Hoover, J. R. E.; Dunn, G. L.; Actor, P.; Uri, J. V.; Weisbach, J. A. J. Antibiot. 1975, 28, 463.

9. Fahmy, S. M.; Badran, A. H.; Elnagdi, M. H. Chem. Tech. 1980, 30, 390.

10. Fahmy, S. M.; El-Hosami, M.; Elgamal; S.; Elnagdi, M. H. J. Chem. Technol. Biotechnol. 1982, 32, 1042.

11. Elnagdi, M. H.; Elmoghayar, M. R. H.; Hammam, A. E. G.; Khallaf, S. A. J. Heterocycl. Chem. 1979, 16, 1541.

12. Elmoghayar, M. R. H.; Elnagdi, M. H.; Ibrahim, M. K. A.; Sallam, M. M. M. Helv. Chim. Acta 1977, 60, 2171.

13. Elnagdi, M. H.; Elfahham, H. A.; Ghozlan, S. A. S.; Elgemeie, G. E. H. J. Chem. Soc., Perkin Trans. 1 1982, 2667.

14. Elmoghayar, M. R. H.; Elmoghayar, M. R. H.; Elghandour, A. H. H.; Elnagdi, M. H. Synthesis 1981, 635.

15. Gorolets, N. Y.; Yousefi, B. H.; Belaj, F.; Kappe, C. O. Tetrahedron 2004, 60, 8633.

16. Gewald, V. K.; Hofmann, I. J. prakt. Chem. 1969, 311, 702.

17. Drummond, J. T.; Johnson, G. J. Heterocycl. Chem. 1988, 25, 1123.

18. Mohareb, R. M.; Sherif, S. M. Sulfur Lett. 1992, 15, 91; Chem. Abstr. 1993, 118, 80892k.

19. Gtylbudagyan, A. L.; Akopyan; M. E.; Vartanyan, R. S.; Sheiranyan, M. A. Hayastani Kimiakan Handes 2002, 55, 58; Chem. Abstr. 2003, 139, 307714. 
20. Abdel-Galil, F. M.; Abdel-Motaleb, R. M.; Elnagdi, M. H. An. Quim., Ser. C 1988, 84, 19; Chem. Abstr. 1989, 110, 75387.

21. Elgemeie, G. E. H.; Metwally, N. H. J. Chem. Res., Synop. 1999, 384.

22. Vosrova, L. M.; Grenad'orova, M. V.; Klad'ko, L. G. Uk. Khim. Zh. 2004, 70, 115; Chem. Abstr. 2004, 142, 392328.

23. Mohammed, Y. S.; Regaila, H. A. A.; Gohar, A. K. M. N.; Abdel-Latif, F. F.; Ahmed, E. Kh. Egypt. J. Pharm. Sci. 1988, 29, 419; Chem. Abstr. 1989, 110, 231374.

24. Hussein, A. H. M. Z. Nat. forsch., B. J. Chem. Sci. 1998, 53, 488; Chem. Abstr. 1998, 129, 16091.

25. Löwe, W.; Bischoff, S.; Wéber, M.; Perpetuo, G.; Luger, P. J. Heterocycl. Chem. 1995, 32 , 249.

26. Abdel-Rahman, R. M. Indian J. Chem., Sect.B 1998, 27B, 548.

27. Ghoneim, K. M.; El-Basil, S.; Osman, A. N.; Said, M. M.; Megahed, S. A. Rev. Roum. Chim. 1991, 36, 1355; Chem. Abstr. 1992, 117, 131111u.

28. Mohareb, R. M.; Sherif, S. F.; Gaber, H. M.; Ghabrial, S. S.; Aziz, S. I. Heteroatom Chem. 2004, 15, 15.

29. Mohareb, R. M.; Aziz, S. I.; Abdel-Sayed, N. I.; El-Banna, A. H. J. Chem. Res., Synop. 1999, 10.

30. Fahmy, H. T. Y.; Rostom, S. A. F.; Bekhit, A. A. Arch. Pharm. Pharm. Med. Chem. 2002, 5, 213.

31. Dobosz, M.;Pachuta-Stec, A. Acta Pol. Pharm. 1995, 52, 103; Chem. Abstr. 1995, 123, 339910.

32. Demirbas, N.; Demirbas, A.; Sancak, K. Turk. J. Chem. 2002, 26, 801.

33. Mekheimer, R. A.; Shaker, R. M. J. Chem. Res., Synop. 1999, 76.

34. Ikizler, A. A.; Ikizler, A.; Uzunismail, N. Org. Prep. Proced. Int. 1992, 24, 365.

35. Golovko, T. V.; Solov'eva, N. P.; Anisimova, O. S.; Granik, V. G. Chem. Heterocycl. Compd. 2003, 39, 344.

36. Hester, J. B., Jr. US Patent 1977, 012, 413; Chem. Abstr. 1977, 87, 53405p.

37. Elmoghayar, M. R. H.; Ghali, E. A.; Ramiz, M. M. M.; Elnagdi, M. H. Liebigs Ann. Chem. 1985, 10, 1962.

38. Gmaj, J.; Sosnowski, C.; Zaremba, Z.; Mrowinski, B. Polish Patent 1990, 88,272649; Chem. Abstr. 1991, 114, 64264.

39. Elgemeie, G. E. H.; El-Ezbawy, S. R.; Ramiz, M. M.; Mansour, O. A. Org. Prep. Proced. Int. 1991, 23, 645.

40. Gutcait, A.; Belyakov, S. V.; Gudriniece, E.; Bleidelis, J.; Mishnev, A. F.; Kramina, M. Kimijas Serija 1986, 5, 607; Chem. Abstr. 1987, 107, 58776.

41. Elmoghayar, M. R. H.; Elagamey, A. G. A.; Nasr, M. Y. S.; Sallam, M. M. M. J. Heterocycl. Chem. 1984, 21, 1885.

42. Basyouni, W. M. Acta Chem. Slov. 2003, 50, 223; Chem. Abstr. 2003, 140, 111344. 
43. Al-Najjar, A. A.; Amer, S. A.; Riad, M.; Elghamry, I.; Elnagdi, M. H. J. Chem. Res., Synop. 1996, 296.

44. Abdel-Latif, F. F.; Mekheimer, R.; Ahmed, E. Kh.; Abdel-Aleem, T. B. Pharmazie 1993, $48,736$.

45. Elmoghayar, M. R. H.; Elagamey, A. G. A.; Nasr, M. Y. A.; Sallam, M. M. M. J. Heterocycl. Chem. 1984, 21, 1885.

46. Hussein, A. H. M. Heteroatom Chem. 1997, 8, 1.

47. El-Rady, E. A.; Khalil, M. A. J. Chin. Chem. Soc. 2004, 51, 779; Chem. Abstr. 2004, 142, 219224.

48. Zayed, E. M.; Hafez, E. A,; Ghozlan, S. A. S.; Ibrahim, A. A. H. Heterocycles 1984, 22 , 2553.

49. Martin, N.; Seoane, C.; Soto, J. L. Heterocycles, 1985, 23, 2013.

50. Elgemeie, G. H; Sayed, S. H. Phosphorus Sulfur Silicon Rel. Elem. 2003, 178, 465.

51. Elgemeie, G. E. H.; Elghandour, A. H. H.; Ali, H. A.; Abdel-Azzez, H. M. J. Chem. Res., Synop. 1999, 6.

52. Beckmann, S.; Schefczik, E. Eur. Patent 1994, 628,547; Chem. Abstr. 1995, 122, 213936.

53. Mandour, A. H.; Fathalla, O. A.; Basyouni, W. M. Biomed. Prob. 2000, 60, 53; Chem. Abstr. 2001, 135, 318456.

54. Bakeer, H. M. J. Serb. Chem. Soc. 1992, 57, 725; Chem. Abstr. 1993, 118, 147532p.

55. Bakeer, H. M. J. Indian Chem. Soc. 1992, 69, 314; Chem. Abstr. 1993, 118, $191683 n$.

56. Elzanate, A. M. Heterocycl. Commun. 2002, 8, 145.

57. Doss, S. H.; Louca, N. A.; Elmegeed, G. A.; Mohareb, R. M. Arch. Pharmacal Res. 1999, 22, 496; Chem. Abstr. 2000, 132, 64443y.

58. Abdel-latif, F. M. Asian J. Chem. 1993, 5, 184; Chem. Abstr. 1993, 118, 124488q.

59. Sofan, M.A.; Metwally, M. A.; Amer, F. A. J. Serb. Chem. Soc. 1993, 58, 731; Chem. Abstr. 1995, 122, 31300.

60. Hammed, M. A.; Kamel, M. M.; Abbasi, M. M.; El-Wassimi, M. T.; Hassan, H. N. A. Pharmazie 1986, 41, 141.

61. El-Wassimy, M. T. M. Sohag Pure Appl. Sci. Bull. 1991, 7, 1; Chem. Abstr. 1993, 118, $212962 \mathrm{v}$.

62. Balicki, R.; Kaczmarek, L.; Nantka-Namirski, P. Acta Pol. Pharm. 1976, 33, 289; Chem. Abstr. 1977, 87, 39357.

63. Hadi, A.; Martin, N.; Mendez, C.; Quinteiro, M.; Seoane, C.; Soto, J. L.; Albert, A.; Cano, F. H. J. Chem. Soc., Perkin Trans. 1 1993, 15, 1743; Chem. Abstr. 1994, 120, 54480w.

64. Erian, A. W.; Aziz, S. I.; Negm, A. M.; Sherif, S. M. J. Chem. Res., Synop. 1993, 352; Chem. Abstr. 1994, 180, 217523d.

65. Gohar, A. M. N.; Abdel-Latif, F. F.; El-Ktatny, M. S. Indian J. Chem., Sect. B 1986, 25B, 404.

66. AL-Njjar, A. A.; Amer, S. A. R.; Raid, M.; Elghamry, I.; Elnagdi, M. H. J. Chem. Res., Synop. 1996, 296. 
67. El-Hamid, I. A. Afinidad 1996, 53, 410; Chem. Abstr. 1997, 126, 144228y. El-Hamid, I. A. Pharmazie 1996, 51, 982; Chem. Abstr. 1997, 126, 47165t.

68. Martin, N.; Quinterio, M.; Seoane, C.; Soto, J. L.; Fonseca, I.; Florencio, F.; Sanz, J. J. Org. Chem. 1990, 55, 2259.

69. Hussein, A. M.; Sherif, S. M.; Atalla, A. A. Polish J. Chem. 1996, 70, 872; Chem. Abstr. 1996, $125,195525$.

70. Metwally, N. H.; Abdelrazek, F. M. Synth. Commun. 2005, 35, 2481.

71. Abu-Elmaati, T. M.; El-Taweel, F. M.; El-Mougi, S. M.; Elagamey, A. G. A. J. Heterocycl. Chem. 2004, 41, 655.

72. Eldin, S. M.; Eldin, A. A. M.; Basyouni, W. M. Arch. Pharm. Res. 1993, 16, 318; Chem. Abstr. 1994, 121, 83091.

73. Hishmat, O. H.; El-Diwani, H. I.; Bakr, S. M. A.; Mahmoud, S. S.; Nada, S. A. Arch. Pharm. Res. 1993, 16, 166; Chem. Abstr. 1994, 120, 315144.

74. Hishmat, O. H.; El-Diwani, H. I.; Melek, F. R.; El-Sahrawi, H. M. Indian J. Chem., Sect. B 1996, 35B, 30.

75. Soliman, A. M.; Sultan, A. A.; El-Shafei, A. K. Monatsh. Chem. 1995, 126, 615.

76. Raid, B. Y.; Hassan, S. M. Sulfur Lett. 1989, 10, 1; Chem. Abstr. 1990, 113, 6091.

77. Kamal-Eldeen, A. M.; El-Gaby, M. S. A.; Gaber, A. M.; Al-Kamali, A. S. N. Phosphorus, Sulfur and Silicon and Relat. Elem. 2005, 180, 418

78. Amer, A. M.; El-Mobayed, M.; Ateya, A. M.; Muhdi, T. S. Monatsh. Chem. 2002, 133, 79.

79. Lipunova, G. N.; Nosova, E. V.; Charushin, V. N.; Chasovskikh, O. M. Chem. Heterocycl. Compd. 2001, 37, 1278.

80. Abdelrazek, F. M. Synth. Commun. 2005, 35, 2251.

81. Elgemeie, G. E. H.; El-Ezbawy, S. R.; Ali, H. A. Synth. Commun. 2001, 31, 3459.

82. Ibrahim, N. S.; Hafez, E. A. A.; Mohareb, R. M. Heterocycles 1986, 24, 2085.

83. Gohar, A. K. M.; Abdel-Latif, F. F.; Regaila, H. A. A. Indian J. Chem., Sect. B 1986, 25B, 767.

84. Abdel-Rahman, R. M. Commun. Fac. Sci. Uni. Ank., B. Chimie 1986, 32, 87; Chem. Abstr. 1988, 109, 6480.

85. Kandeel, Z. E. J. Chem. Res., Synop. 1995, 291.

86. Rida, S. M.; Habib, N. S.; Badwey, E. A. M.; Fahmy, H. T. Y.; Ghozlan, H. A. Pharmazie 1996, 51, 927.

87. Benoit, R.; Grote, T.; Bayer, H.; Mueller, B.; Oberdorf, K.; Sauter, H.; Ammermann, E.; Lorenz, G.; Strathmann, S. PCT Int. Appl. WO Patent 1996, 9635, 690; Chem. Abstr. 1997, $126,59966 \mathrm{t}$.

88. Metwally, N. H.; Abdelrazek, F. M.; J. Prakt. Chem.Chem-Ztg. 1998, 340, 676; Chem. Abstr. 1999, 130, 13960r.

89. Abu-Elmaati, T. M.; El-Taweel, F. M.; Elmougi, S. M.; Elagamey, A. J. Heterocycl. Chem. 2004, 41, 655 . 
90. Abed, N. M.; Elagamey, A. G. A.; Harb, A. F. A. J. Chem. Soc. Pak. 1988, 10, 151; Chem. Abstr. 1989, 110, 173140p.

\section{Biographical Sketches}

\section{Dr. Samir Bondock}

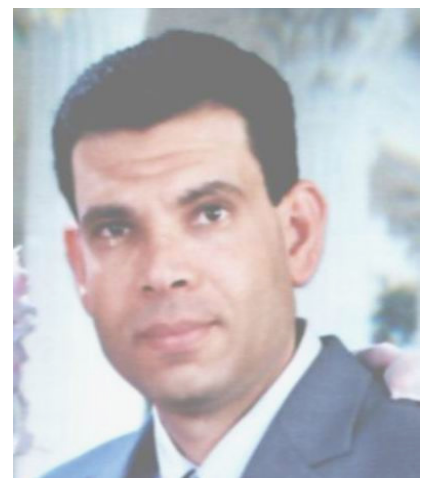

Samir Bondock was born in 1970 in Mansoura, Egypt and received his M.Sc. thesis on synthesis of some new azo disperse dyes for dyeing synthetic fibers from the University of Mansoura in 1995 under the supervision of professor A. A. Fadda. He performed his Ph.D. thesis in the research group of Professor A. G. Griesbeck in Cologne, Germany where he graduated in 2003 on spin-mapping effects and photoaldol reactions. Since 2003, he has been a lecturer at the University of Mansoura. His research interest is the synthesis of heterocyclic compounds with pharmaceutical interest using thermal and [2+2] photochemical reactions.

\section{Abd El-Gaber El-Tarhoni}

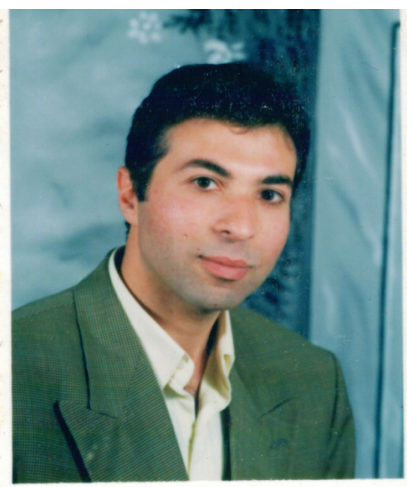

Abd El-Gaber El-Tarhoni was born in 1964 in Mansoura, Egypt and studied chemistry at the University of Mansoura. In 1986, he obtained his B.Sc. He performed his M.Sc. thesis in the research group of Professor A. A. Fadda on azo disperse dyes and their availability for dyeing synthetic fibers. 


\section{Prof. Ahmed Ali Fadda}

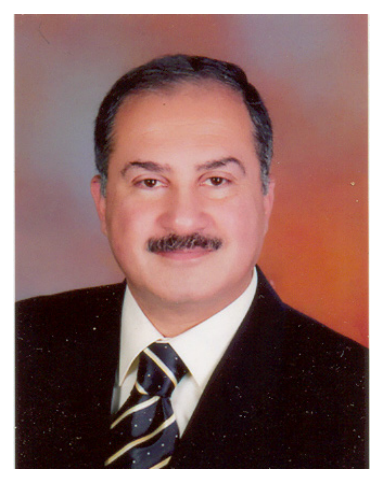

Prof. A. A. Fadda was born in 1950 in Cairo, Egypt. He received both his B.Sc. degree (1971) from Cairo University and his M.Sc. (1976) degree from Mansoura University. He performed his Ph.D. thesis in the research group of Professor A. N. Kost at Moscow University, Russia where he graduated in 1981 chemistry of pyridine rearrangement. Since 1991, he has been a professor of organic chemistry at the University of Mansoura. Prof. Fadda is the author of over 130 scientific papers on heterocyclic chemistry, dyes chemistry and synthetic methodology. His research interests cover the development and mechanistic understanding of organic reactions and their applications in dyes and medicinal chemistry. 